A VIBEYOR

Earth Science and Geophysics

ISSN: 2631-5033

\title{
Important of Gossans in Mineral Exploration: A Case Study in Northern Turkey
}

\section{Ozdemir $A^{1^{*}}$ and Sahinoglu $A^{2}$}

\author{
${ }^{1}$ Adil Özdemir Mühendislik, Öveçler Mah Çankaya, Ankara, Turkey \\ ${ }^{2}$ Istanbul Rumeli Üniversitesi, Meslek Yüksek Okulu, Istanbul, Turkey
}

\begin{abstract}
Gossan is intensely oxidized, weathered or decomposed rock, usually the upper and exposed part of an ore deposit or mineral vein. In the $19^{\text {th }}$ and $20^{\text {th }}$ centuries gossans were important guides to buried ore deposits used by prospectors in their quest for metal ores. An experienced prospector could read the clues in the structure of the gossans to determine the type of mineralization likely to be found below the iron cap. Two marked types of gossans within study area are greyish red, heavy, massive limonite and light red, light and poorly porous limonite. Both of these two types are usually very hard and display local brecciated structures. The size of pieces of breccia is average $5 \mathrm{~cm}$ and pieces are either composed of locally earthy limonite with goethite or of fine grain quartz. They are placed in limonite matrix with some secondary quartz. There are 8 gossans outcrops in NE-SW orientation in the area of $1.6 \mathrm{~km}$ in length among units targeted for mineralization. The presence of these gossans indicates that here may be mineralization within the study area. Gossans located in the southwest have a higher Cu value compared to gossans in the southeast. Except for a sample collected from gossans in the northeast, remaining samples do not have lead anomaly. Samples collected from gossans in the southwest have a zinc anomaly. The presence of cobalt is a significant indicator of a VMS-type mineralization. A limited number and depth of boreholes were made to exploration for copper ore in study area, and laboratory analyses were performed on limited number of core samples from boreholes. In the study area and surroundings, metamorphic units of pelitic schist, mafic volcanoclastic targeted for VMStype mineralization and thrusting ultramafic rocks are located to the south of study area.
\end{abstract}

Keywords

Gossan, Copper mineralization, VMS deposit, Massive sulfide, Central Pontides

\section{Introduction}

The study area is located within Kastamonu and Sinop in the Central Pontides (Figure 1). A large number of rural settlements exist in the study area. The site includes rough terrains and forestlands. The area is located in the northeast to Ilgaz Mountains. The major elevation of the area is Elekdag. The study area are contained in the Central Black Sea region and substantially represent geographical, climatic and demographical characteristics of the area. Topographically, the area appears highly rough, therefore settlements are scattered across the area.

The Kastamonu-Sinop area is located in the Mesozo-
ic-Tertiary central of pontide metallogenic belt. This area was under influence of Alp-Tethyan orogenesis and important ore deposits are formed in this area. The eastern Pontide from Samsun to Trabzon is famous Cretaceous felsic dominant volcanic VMS (Volcanogenic Massive Sulfide) $\mathrm{Cu}-\mathrm{Au}, \mathrm{Pb}-\mathrm{Zn}-\mathrm{Ag}$ deposits. The central part of the same belt, that is Kastamonu, contains rather older mafic volcanic Cyprus-type $\mathrm{Cu}$ deposits. The best example would be Küre mine with 40 million ton reserve. In addition, Eti Bakir A.Ş has a smelter in Samsun. New copper deposits have been explored by exploration works performed on ophiolitic field near Kastamonu (particularly) Hanönü district over last five years. The examples

${ }^{*}$ Corresponding author: Ozdemir A, Adil Özdemir Mühendislik, Öveçler Mah. 1322 Sok. 60/5 Çankaya, Ankara, Turkey, E-mail: adilozdemir2000@yahoo.com

Received: April 06, 2018: Accepted: June 13, 2018: Published: June 15, 2018

Copyright: ( 2018 Ozdemir A, et al. This is an open-access article distributed under the terms of the Creative Commons Attribution License, which permits unrestricted use, distribution, and reproduction in any medium, provided the original author and source are credited. 


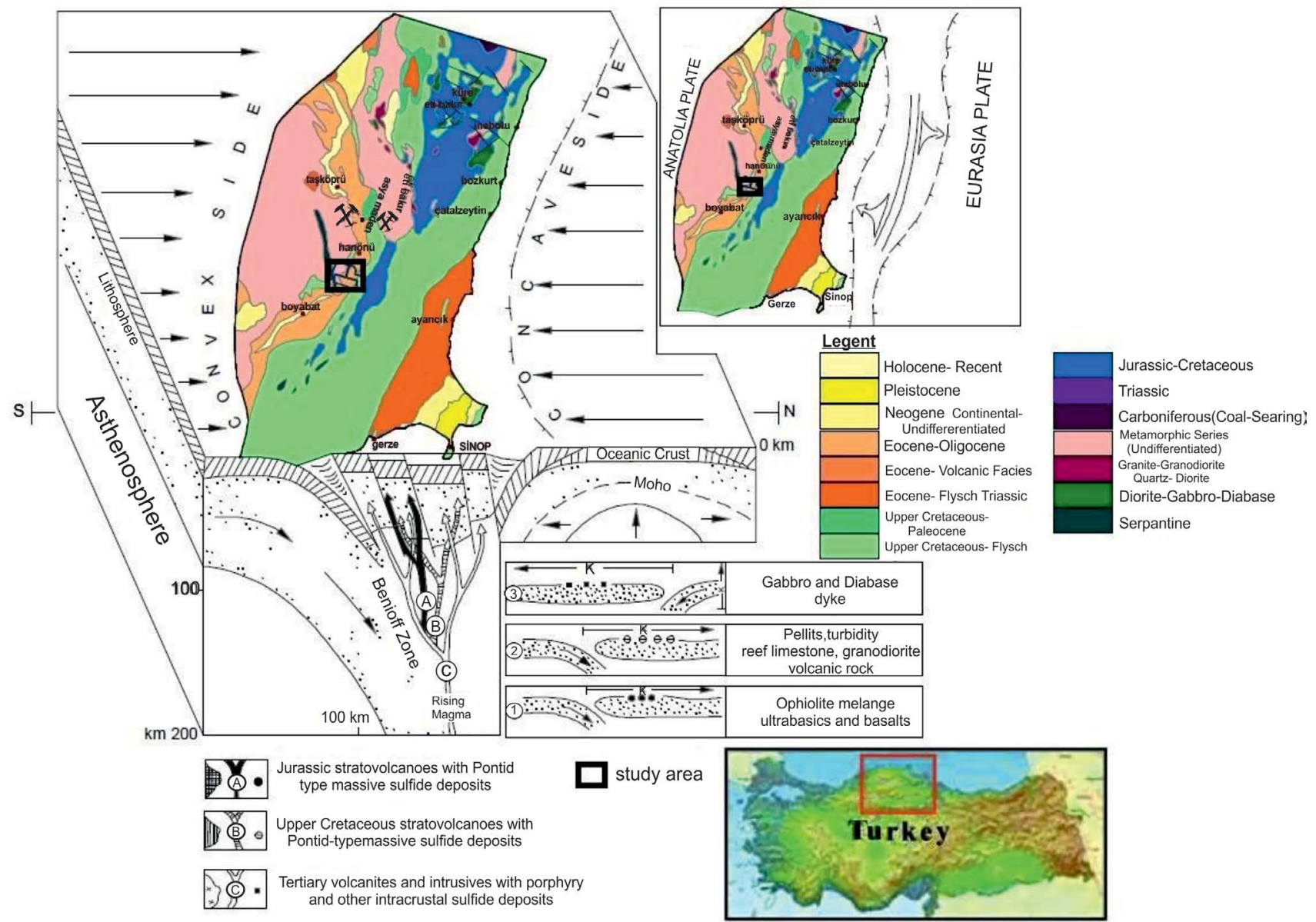

Figure 1: Formation model of massive sulfide deposits associated with plate tectonics in the Central Pontides. The upper right corner shows local position of the arch and lower right corner shows evolution order and orientation of movement and sedimentation of alkaline (magmatic) front [16].

would be Hanönü with estimated reserve of 20 million ton (feasibility study performed by Asya Maden İşletmeleri A.Ş), Cozoğlu mine with known reserve of 1 million tone owned by Eti Bakir A.Ş (Figure 1).

The Kastamonu-Sinop area is on Intra-Pontid suture zone. It is composed of Paleotethys stratigraphic units and Neotethys units covering Paleotethys units. For VMS, Triassic-Jura volcanic arch, ophiolitic mélange and associated accretionary prism containing schist and covering young areas make up the targeted stratigraphy. In the area, targeted formations for VMS deposits include Akgöl and Bekirli Formations composed of phyllite, pelitic schist, carbonaceous schist, mafic volcanoclastic, gneiss, marble, calcschist and metadiabase gabbro up to $2000 \mathrm{~m}$ in thickness referenced in MTA (General Directorate of Mineral Research and Exploration of Turkey) and other sources.

The model of geodynamic system formed the Central Pontides (Central Pontides) complex volcanic arch within study area is created by associating remnants of the arch based on current information of the relevant area; movements of alkaline (magmatic) front and tectonic units, movements and weathering during the evolution period of the arch. This adopted approach has facilitated opinions on spaces where axial part of complex arch and especially massive sulfide deposits are originated. Figure 1 gives a general overview of the Central Pontides complex volcanic arch which is convenient for originating of magma and ore metals in any aspect. Mineralization within study area dates back to Jurassic (Liassic) period and at that time Pontides were in the position of an island arch. The wall rock of mineralization is tholeiite basalts, the initial product of island arch volcanism, and they are derived from a hybrid magma, a mixture of materials both from oceanic shell and continental shell. Because these deposits are older (Liassic) than other massive sulfide deposits in Pontides (for example, Mesozoic Murgul deposits), this proves that they were formed during first steps of island arc process. In the study area, rocks that are locally referred to as Akgöl formation are mostly metamorphic. In general, there is a very thick black shale (claystone)-sandstone sequence on these massive sulfide-type deposits, and detritic rocks indicate a media shallower than $200 \mathrm{~m}$ [1].

Faults and fractures were observed due to impact of north-to-south compression. Repeating dip-slip faults exist in the north segment and strike-slip faults and dipslip faults exist in the center and at the edges of study 


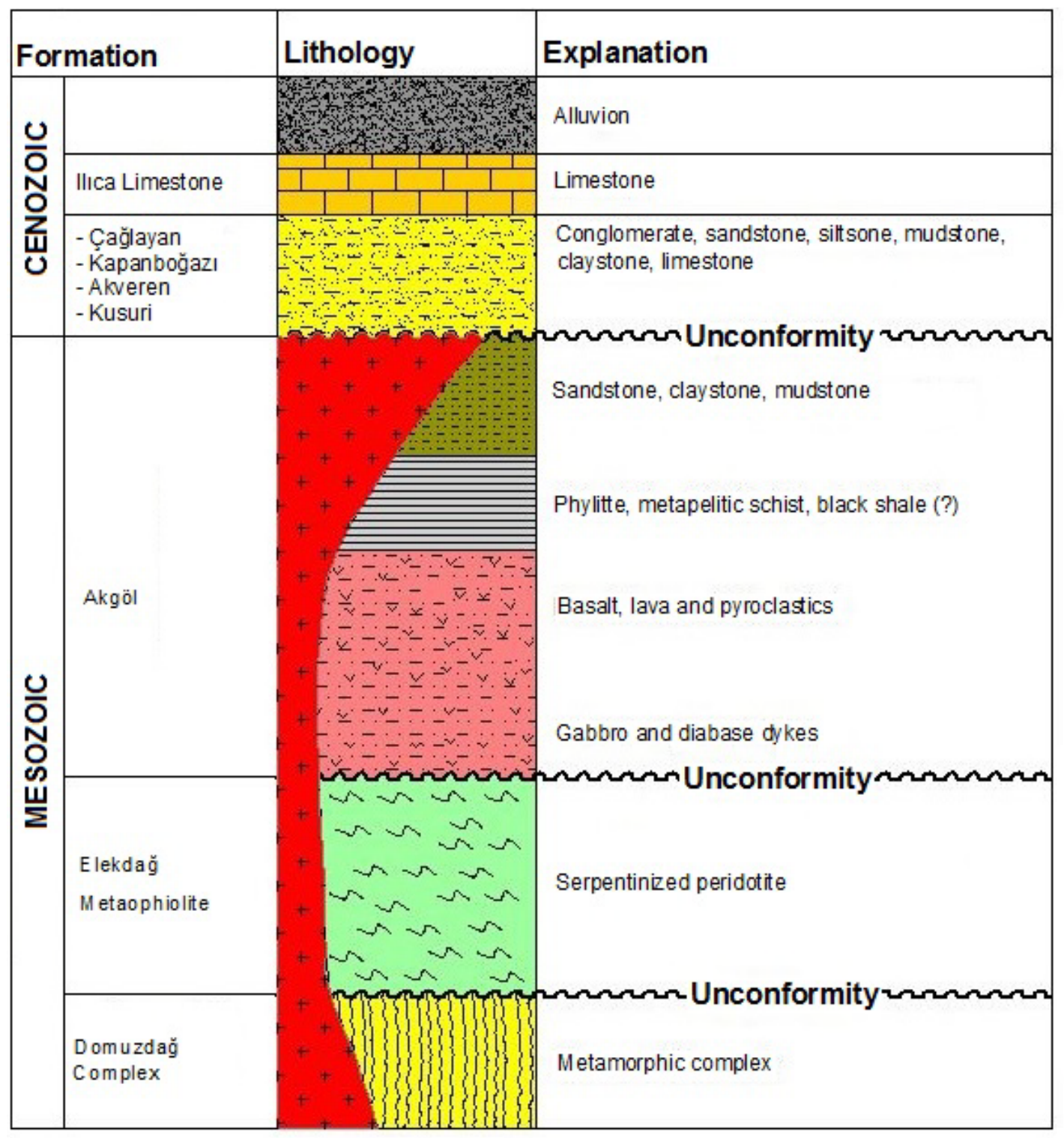

Figure 2: Stratigraphic vertical section of study area (No scale) [1].

area. In general, the slope of layers is in the north orientation in the study area. Gossans (surface argillisation-hematization-limonitization) outcrops of $1.6 \mathrm{~km}$ in the NE-SE orientation are found within prospective units. The presence of these gossans indicates that here may be mineralization within the study area. Because of the presence of gossans, detailed geochemical studies were conducted in the south section of study area.

\section{Geology of Study Area}

Rocks within the study area are divided into three groups (bottom-to-top): Mafic and Ultramafic Rocks Pre-Liassic period (Elekdağ Meta-ophiolite) and Domuzdağ Metamorphic complex, Liassic Akgöl formation and sediment units after Liassic period. Furthermore, there are volcanic rocks such as gabbro and diorite dykes intruded into some of these rocks. To the south of study area, Elekdağ Meta-ophiolite and Domuzdağ complex Pre-Liassic aged and volcanic-subvolcanic units referred to as Akgöl formation and metamorphosed in greenschist fasies, and to the south sediment units after Liassic age are surfaced (Figure 2, Figure 3 and Figure 4) [1].

To the south of study area, Elekdağ Meta-ophiolite of $35 \mathrm{~km}$ in length and 3-4 km in width is located in SWNE orientation with no uniform stratigraphic position, tectonic contact with each other, mafic in lenses and intermittent slices (massive metagabbro, layered gabbro lenses, and isolated diabase-microgabbro-pegmatitic gabbro dykes cutting the entire sequence) and ultramafic (serpentinite, serpentinitized peridotite). Upper section of Elekdağ Meta-ophiolite (plate dykes, mafic lavas, and pelagic sediment) is not preserved. The lower contact of Elekdağ Meta-ophiolite has blueschist of Domuzdağ 1 Metamorphic complex associated with tectonic [1].

Akgöl Formation, first defined by Yilmaz and Tüysüz [2], is composed of sediment-based phyllite, schist and 

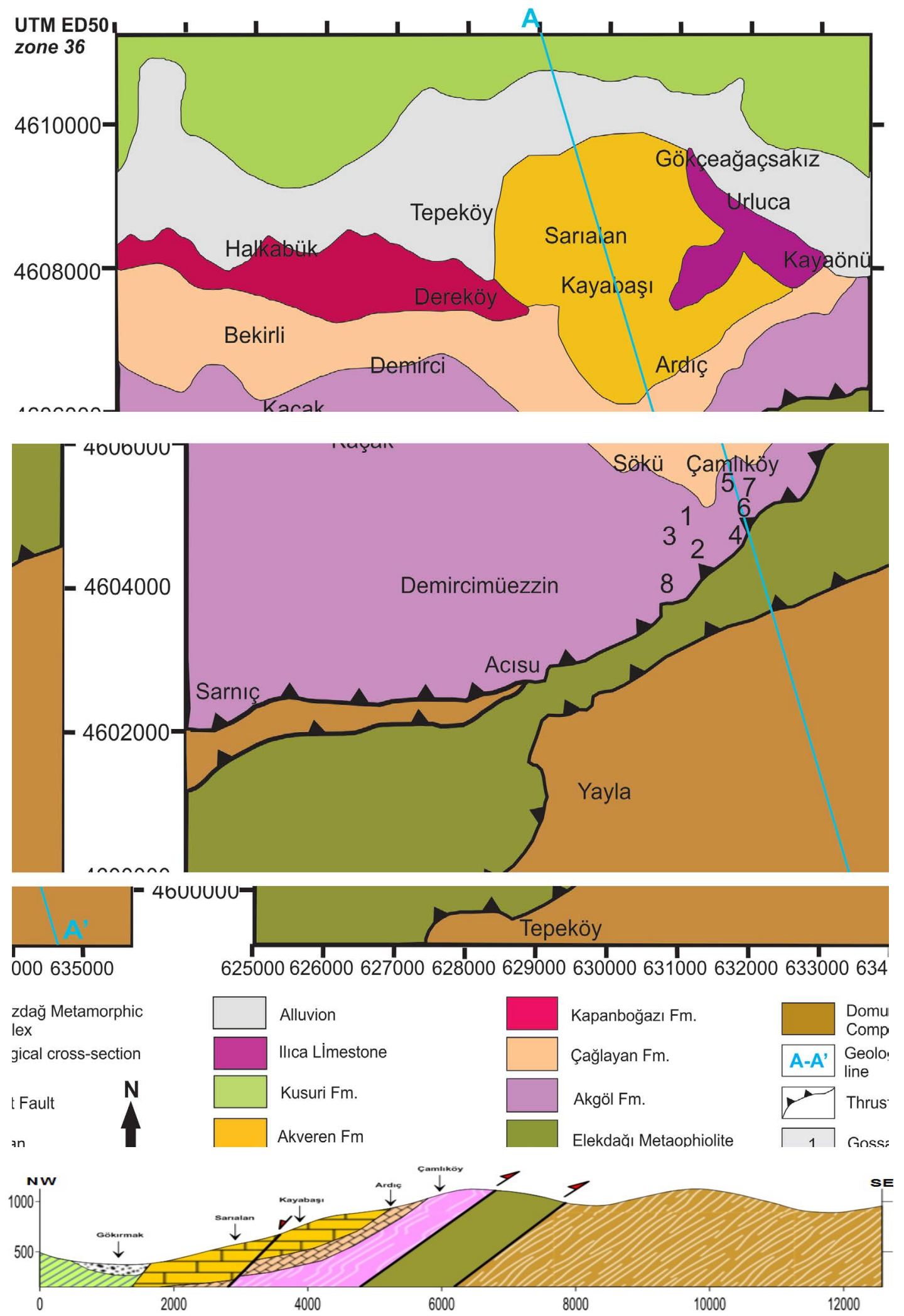

Figure 3: Location of gossans on the geological map [1].

metadiabase primarily associated with them and subsequently defined by Sütçü, et al. [3] as a formation that mostly has alkaline metalava and metatuff, and less schist and phyllite in parts. The unit is composed of metalava with abundant garnets and glaucophane, metapelitic sediment and metadetritic sediment. Akgöl Formation, located in the area between Çangaldağ and Elekdağ and defined by Ustaömer and Robertson [4] as Bayam melange, was referred to as Gökbelen Formation by Eren [5].

Akgöl Formation tectonically obducts Elekdağ Meta-ophiolite and is inharmoniously obducted by the Up- 

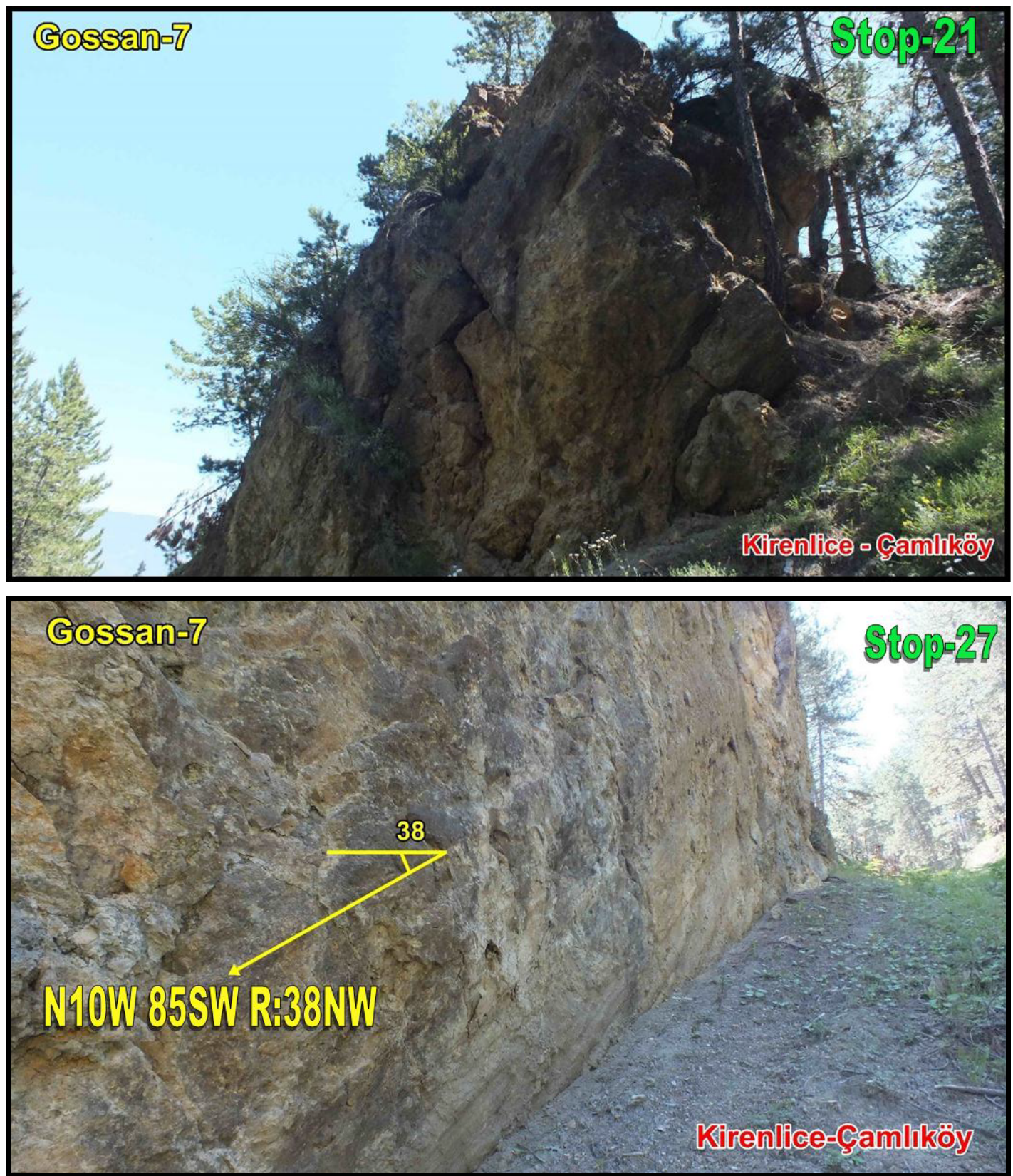

Figure 4: Gossan-7 formed close to the contact of metamorphics of Akgöl Formation and ophiolites of Elekdağ and scissor fault plane in NS orientation near Kirenlice-Çamlıköy.

per Cretaceous Çağlayan Formation. The sequence is primarily made of alkaline metalava and metatufss at the bottom and schist and phyllite at the upper parts. Phyllites among metamorphics where the effect of foliation and folding can be seen are greenish, grey, blackish, fine grained soft-crumbly crops in the topography. Foliation is well established and nacreous due to mica minerals. The schist is yellow, grey and blackish and very well foliated [1].

The schist seen at the lower of phyllite indicates the increased severity of metamorphism. The schist is firmer and relatively coarse grained. The main components of schist are quartz and mica, and garnets and glaucophane minerals are visible. Petrographically, lithology of chlo- rite-epidoteschist, chloric-micaschist, quartz micaschist is identified [6].

Metabasites is a type of rocks that contain dark color minerals such as chlorite, epidote and amphibole as a main mineral in its green tons. In addition to schist texture partly folded, there are sections where no foliation exists. Another characteristic of Akgöl formation is that the upper parts of the sequence has marble lenses. Marble lenses are white-grey in color. The unit was defined by Sütçü, et al. [3] as the member of Demircimüezzin marble in $30-40 \mathrm{~m}$ thick, and correlated by Yilmaz and Tüysüz [2] as a section of Akgöl Formation. The marble is hard and very faulted and the bedding is not established. 


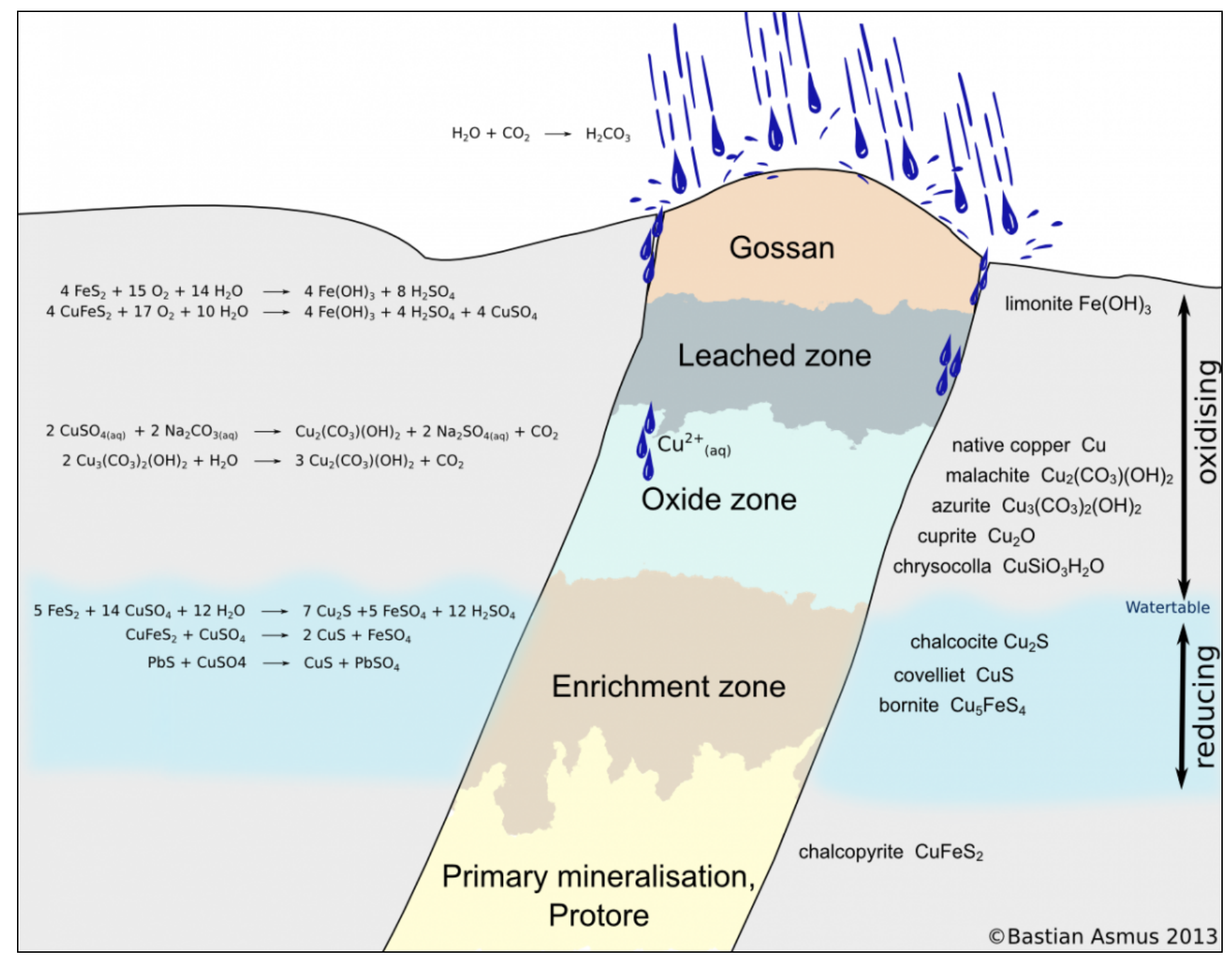

Figure 5: Schematic view of a sulfide vein (http://en.archaeometallurgie.de/gossan-iron-cap/).

There is no evidence to date Akgöl Formation, however the age of the formation is considered Triassic-Liassic because it is cut by Dogger granites, stated to be 170 million years old, transitional with Permian Elekdağ Meta-ophiolite at the bottom, and because it is inharmoniously covered by Malm-Lower Cretaceous İnalt and Çağlayan formations [3]. In the study by Yılmaz and Tüysüz [7], it was considered Pre-Liassic period. Ustaömer and Robertson [4] suggest that this formation is not well established. They consider the unit to belong to Paleo-Tethys and provide and age Pre-Jura.

Akgöl Formation has a reverse fault over mafic and ultramafic rocks (Elekdağ Meta-ophiolite). At lower levels, basaltic volcanic rocks are massive and pillow lava upward and turns into breccia character at upper levels. To the south of study area, there are peristerite phyllite-schist with the low effect of metamorphism, to the north of study area there are black shale (claystone), siltstone, sandstone, and rarely limestone and dolomitic limestone at upper sections. The lower section of this sequence is made of very fine grained black shale and upper section is primarily made of sandstone, considered to be regressive because the grains become larger to the upper section. Basaltic volcanic rocks are particular important as they contain ore deposits, and display massive character at lower levels and pillow lava character to upper levels, the top level has a breccia character. It is partly cut by dykes. Breccia basalts have argely undergone hydrothermal alteration. Massive basalts are green, blackish green, very fine grained and has a subophitic texture. The prevailing mineral is plagioclase and between plagioclase is clinopyroxene. There are secondary quartz formations along the fractures in addition to quartz mineral. Plagioclase has albitization, sericitization and little argillisation. In addition, rock is commonly split and has little amount of epidote, prehnite and opaque minerals. Pillow lavas, indicative of undersea eruption, are greenish gray, greenish black in color. Their long axis ranges from 3-5 $\mathrm{cm} 2-3 \mathrm{~m}$. The longer axis of pillows can be several fold of shorter axis in length. Pillow lavas are mainly composed of plagioclase (labrador) and clinopyroxene. Plagioclases are very fine grained, prismatic, and partly have lathes and micro-phenocrystal, and plagioclase microlites have albitization and sericitization. Partial sericitization and 
chloritization are also observed. Chlorite and carbonate are filled between plagioclases. The rock contains leucoxene. The top levels have breccia basalts. Pillow lavas are transitioned laterally and vertically. The greenish grey breccia structure includes fractures, calcite, chlorite, albite, chert, gypsum, iron oxide and pyrite filled [1].

In the study area, units after Liassic period consist of Çağlayan Formation made of sedimentary units such as limestone, conglomerate, sandstone, siltstone, claystone, and mudstone; Kapanboğazı Formation; Akveren Formation; Kusuri Formation; Ilica limestone and alluvial deposits [1].

\section{Gossans in Study Area}

Gossan is intensely oxidized, weathered or decomposed rock, usually the upper and exposed part of an ore deposit or mineral vein (Figure 5). In the classic gossan or iron cap all that remains is iron oxides and quartz often in the form of boxworks, quartz lined cavities retaining the shape of the dissolved ore minerals. In other cases quartz and iron oxides, limonite, goethite, and jarosite, exist as pseudomorphs replacing the pyrite and primary ore minerals. Frequently gossan appears as a red stain against the background rock and soil due to the abundance of oxidized iron and the gossan may be a topographic positive area due to the abundance of erosion resistant quartz and iron oxides. Although most gossans are red, orange, or yellow, black gossans from manganese oxides such as pyrolusite, manganite, and especially psilomelane form at the oxidized portion of Manganese-rich mineral deposits. In the 19th and 20th centuries gossans were important guides to buried ore deposits used by prospectors in their quest for metal ores. An experienced prospector could read the clues in the structure of the gossans to determine the type of mineralization likely to be found below the iron cap (wikipedia.org/wiki/Gossan).

In the traditional view, supergene ore and gangue minerals are the products of reactions between hypogene sulfide minerals and descending, acidic meteoric waters; these processes take place at or near the ground surface in subaerial environments [8]. In VMS deposits, copper and other metals are mobilized from primary massive sulfide ore and reprecipitated at depth. This precipitation of $\mathrm{Cu}$ sulfides with high $\mathrm{Cu} / \mathrm{S}$ ratios can produce an economically significant copper enrichment at the reactive redox boundary between massive sulfide protore and downward penetrating fluids. The supergene enrichment "blanket" is overlain by an intensely altered and leached Fe oxide-rich gossan (the remains of the original massive sulfide) that extends upward to the paleosurface. Studies of hydrothermal sulfide mounds and chimneys on oceanic spreading axes reveal a second type of gossan formation: oxidation of sulfide minerals by interaction with oxygen-rich ambient seawater. This process, sometimes referred to as "seafloor weathering", is accompanied by formation of secondary, low-temperature $\mathrm{Cu}$ sulfide minerals as well as the $\mathrm{Cu}$ chloride mineral atacamite at the TAG site, Mid-Atlantic Ridge $[9,10]$. Based on observations at TAG, bedded ocher overlying massive sulfide at Skouriotissa, Cyprus, has been reinterpreted as a submarine gossan [11].

In deposits where the zone of weathering is well developed and preserved, the gossan may contain identifiable mineral subzones dominated by sulfates, carbonates, phosphates, or oxides [12]. The chemical compositions of oxidized minerals in gossans reflect, to some extent, the antecedent sulfide mineralogy [13]. For example, high $\mathrm{Pb}$ contents $(\mathrm{Pb}$ tends to be less mobile in these environments) and secondary $\mathrm{Pb}$ carbonate and sulfate minerals (cerussite, smithsonite, anglesite) occur in gossanous zones overlying VMS mineralization containing significant amounts of galena [12]. In deposits of the Bathurst mining camp and the Iberian Pyrite Belt, complex sulfates or sulfate-arsenate minerals such as plumbojarosite and beudantite also act as significant sinks for $\mathrm{Pb}$ in the oxidization zone $[14,15]$.

In the study area, metamorphic units of pelitic schist, mafic volcanoclastic targeted for VMS-type mineralization and thrusting ultramafic rocks are located to the south of study area. Units composed of claystone, limestone, sandstone, siltstone and conglomerate, which are not related to mineralization and are younger than targeted units, and quaternary deposits are located in the north to the study area.

There are 8 gossans outcrops in NE-SW orientation in the area of $1.6 \mathrm{~km}$ in length among units targeted for mineralization. The presence of these gossans indicates that here may be mineralization within the study area. Chemical weatheringis also the cause of formation of gossans and underneath ore deposits. It is a yellow-red color deposit that mainly contains hydrated iron oxide and is washed by oxidation of sulfide minerals such as gossan pyrite $\left(\mathrm{FeS}_{2}\right)$. Sulfuric acid is produced by melting of pyrite and other sulfide minerals, which melts other metallic minerals; and minerals containing copper, lead and zinc are formed in the water table that flow down with melt. Concentration of sulfide minerals under the water table forms the ore mass. Gossans are indicators of more important underlying ore deposits.

The geology of study area and surrounding has been investigated by field surveys performed. The metamorphic units of pelitic schist, mafic volcanoclastic targeted for VMS-type (Volcanogenic Massive Sulfide) mineralization and thrusting ultramafic rocks are located to the south of study area. Units composed of claystone, limestone, sandstone, siltstone and conglomerate, which are 
not related to mineralization and are younger than targeted units, and quaternary deposits are located in the north to the study area.

There are NE-SW-orientation outcrops of gossans that exist in parts in a length of $1.6 \mathrm{~km}$ within the prospective unit and was revealed by works performed on hills to the south of Çamliköy (Figure 3). It is estimated that gossans have a thickness of maximum $30 \mathrm{~m}$. Gossans crop out on the crest of Karakçı Hill facing NE on the forest road, and $250 \mathrm{~m}$ in the northeast of this gossan was found another outcrop of gossans that contain a little of malachite coating. There is a very small piece of gossans found immediately to the south of Tarakçı Hill; however we could not determine where it came from. To the further south, outcrop of gossans exist on the road to the northeast of Besteci hill and $300 \mathrm{~m}$ immediately northeast to these gossans exist small outcrops of gossans and pieces of gossans. The presence of these gossans suggest that there may a significant mineralization within study area.

The size of gossans located within study area is not proportional to the mass of main mineralization. Normally, association of all gossans in a mine site with ore deposits can be directly compared, and in general, they do not go beyond the boundary of ore masses as they form a cover on them. Thickness of limonitic gossans varies between $1 \mathrm{~m}$ to 120 $\mathrm{m}$. Gossans may contain some small and isolated pyritic ore masses. Two marked types of gossans within study area are greyish red, heavy, massive limonite and light red, light and poorly porous limonite. Both of these two types are usually very hard and display local brecciated structures. The size of pieces of breccia is average $5 \mathrm{~cm}$ and pieces are either
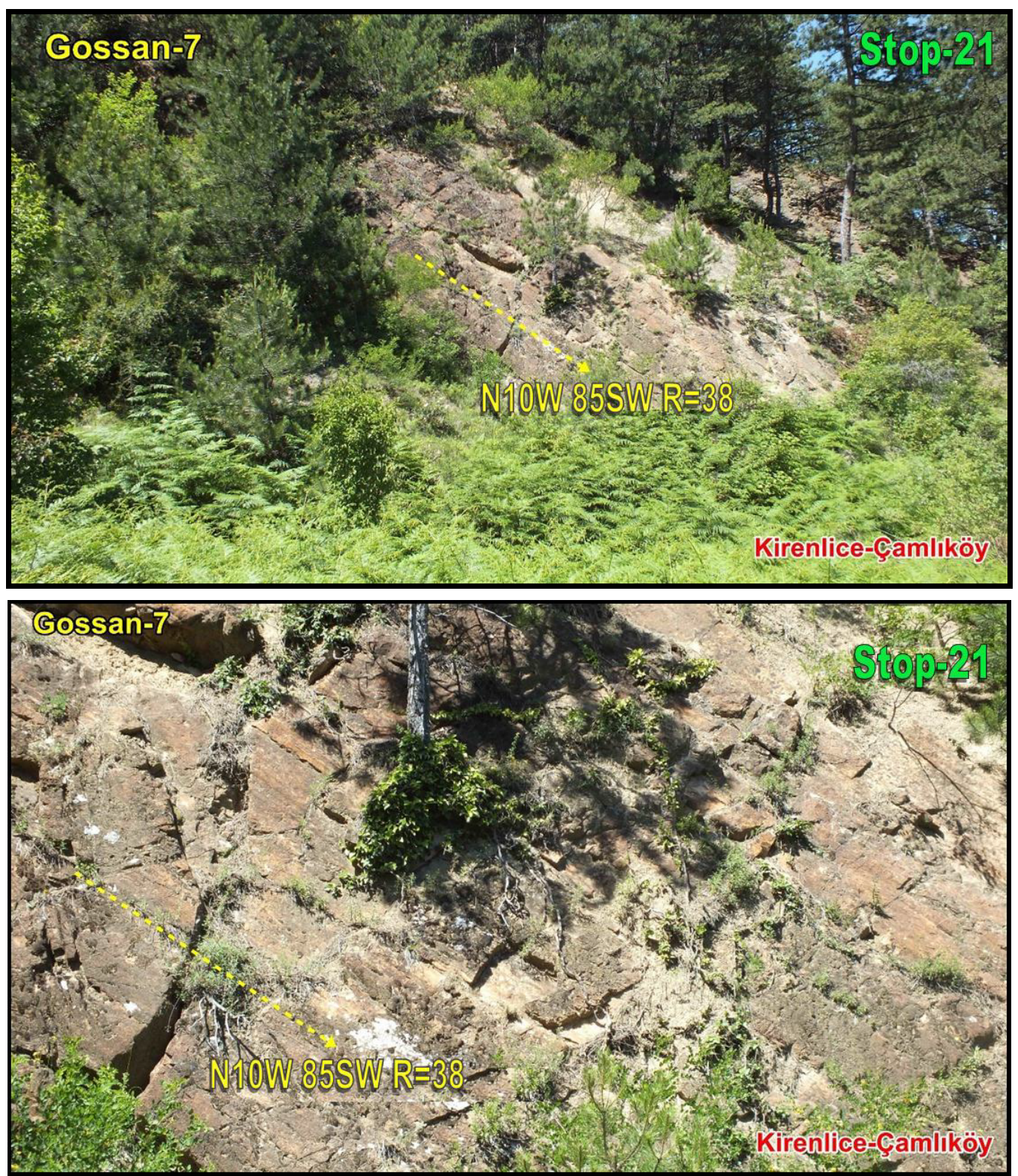

Figure 6: Gossan-7 formed close to the contact of metamorphics of Akgöl Formation and ophiolites of Elekdağ, scissor fault plane in NS orientation and slip lines near Kirenlice-Çamlıköy. 

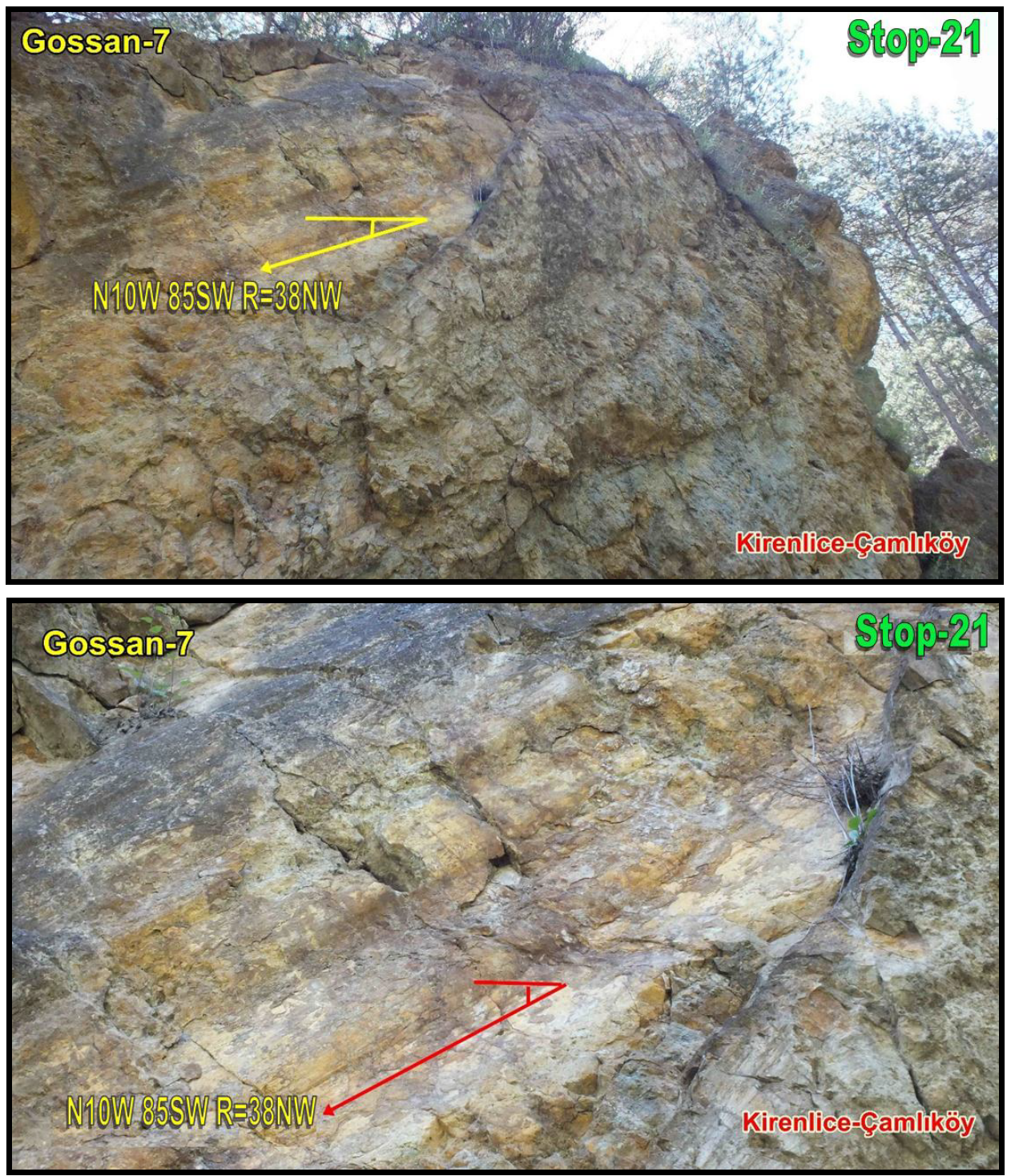

Figure 7: Gossan-7 formed close to the contact of metamorphics of Akgöl Formation and ophiolites of Elekdağ, scissor fault plane in NS orientation and slip lines near Kirenlice-Çamlıköy.

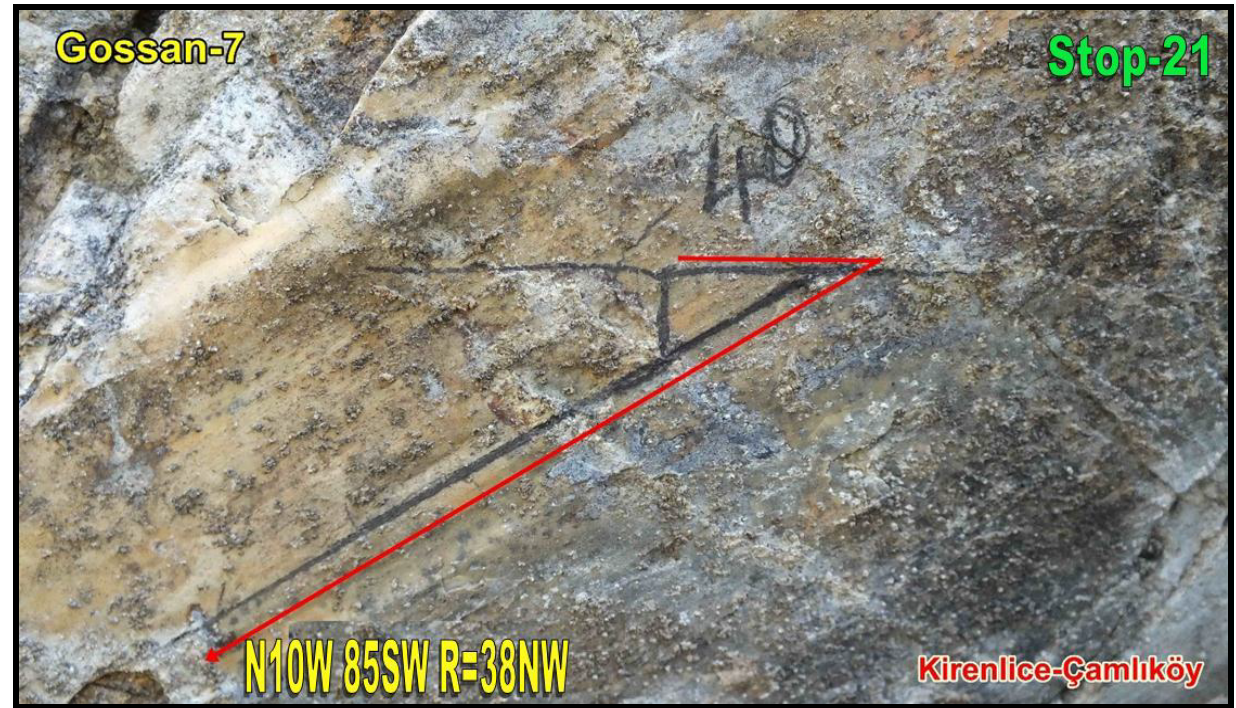

Figure 8: Gossan-7 formed close to the contact of metamorphics of Akgöl Formation and ophiolites of Elekdağ and close view of slip lines in NS-orientation scissor fault plane near Kirenlice-Çamlıköy. 


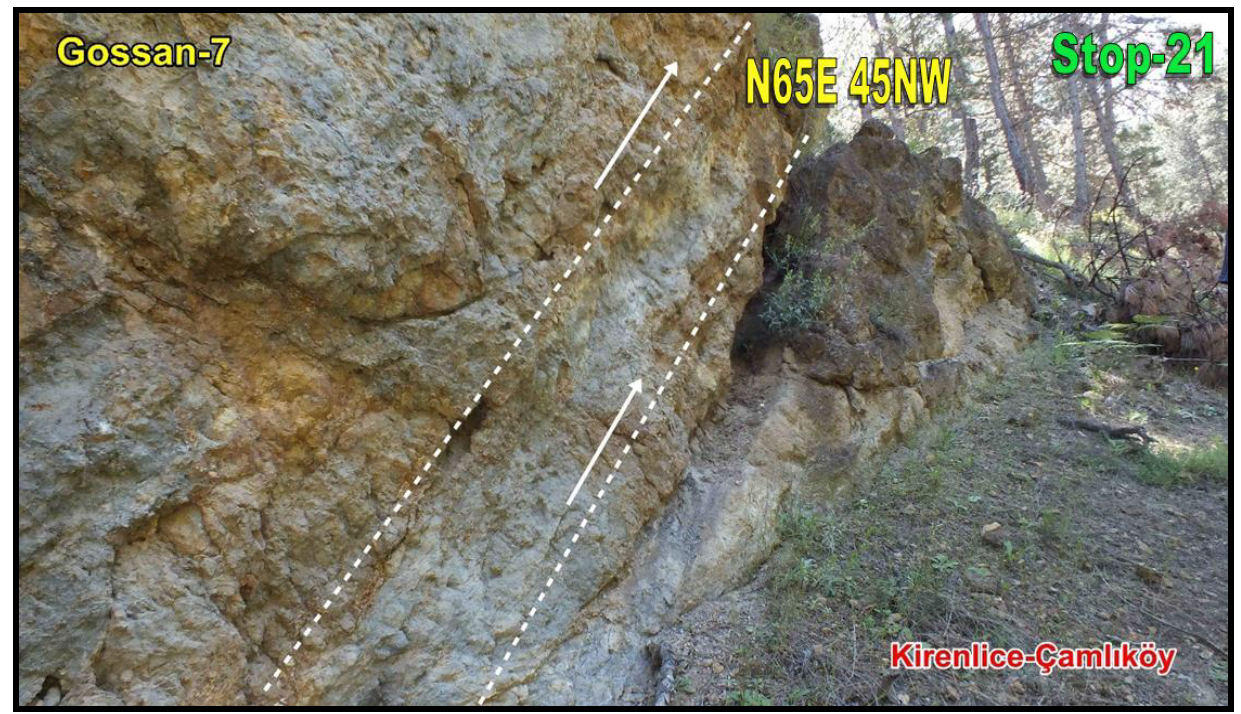

Figure 9: Gossan-7 formed close to the contact of metamorphics of Akgöl Formation and ophiolites of Elekdağ and NE-SWorientation thrust fault near Kirenlice-Çamlıköy.
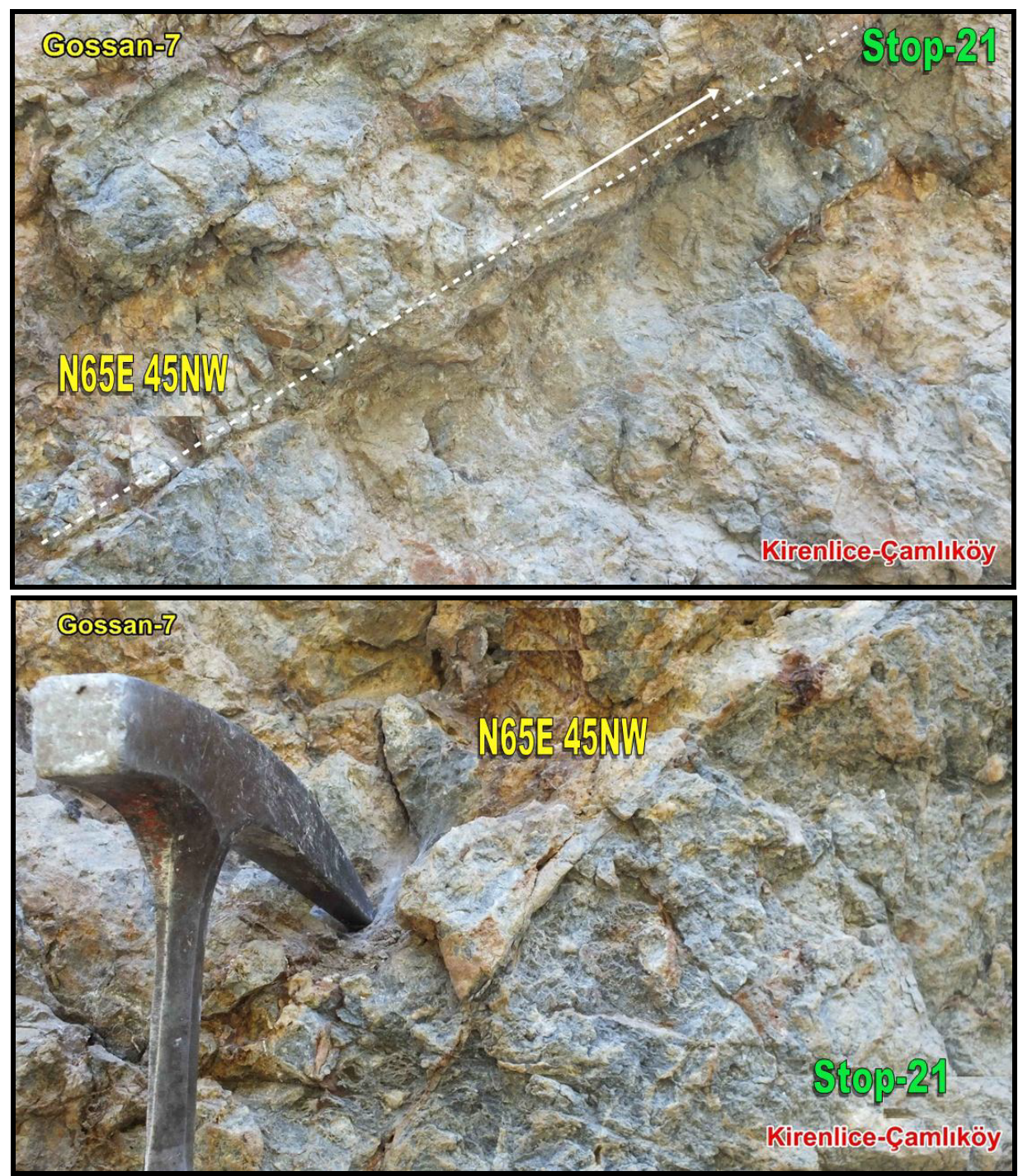

Figure 10: Gossan-7 formed close to the contact of metamorphics of Akgöl Formation and ophiolites of Elekdağ and close view of NE-SW-orientation thrust fault near Kirenlice-Çamlıköy. 
composed of locally earthy limonite with goethite or of fine grain quartz. They are placed in limonite matrix with some secondary quartz.

Gossan-7 is located between Çamlıköy and Kirenlice on the NE slope of Karakc1 Hill (Figure 4). This gossan is contained metamorphics of Akgöl Formation, and Elekdağ thrusting sloped to NW is located approximately 2 $\mathrm{km}$ to the south of this gossan. Thus, the gossan is located very close to the zone where metamorphics of Akgöl Formation overthrusts on Elekdağ ophiolites, within the zone including reverse thrust faults that continue also in metamorphics of Akgöl Formation. Limonitization and hematitization are observed along this gossan.

The gossan is formed in perpendicular to thrust fault and cut and shifted by scissor fault/strike-slip fault in N10W 85SW orientation. Each part of the gossan is located on either side of a ravine extending from $\mathrm{N}$ to $\mathrm{S}$ (Figure 6 and Figure 7). The faulting is a strike-slip fault to the right and its slope was measured as 38-40 degrees
(Figure 8 and Figure 9). A brecciated structure can be seen along the fault plane.

It is considered that there is a scissor between thrust faults orientation in stages of this strike-slip faulting in $\mathrm{N}-\mathrm{S}$ orientation. A similar scissor exists along the Acisu stream in the area. There are N65E 45NW-orientation reverse faults inside the gossan. A thin fault gauge is observed along the reverse faults (Figure 10 and Figure 11).

Gossan-6 is located between Çamlıköy and Kirenlice on the eastern slope of Karakc1 Hill. The gossans are formed in the metamorphics of Akgöl Formation in concordantly with schistosity, orientation measured is $\mathrm{N} 38 \mathrm{E}$ 70NW (Figure 11).

Gossan-3 is located on the northeast slope of Bestici hill between Çamlıköy and Kirenlice. This gossan extends in a linear way and in stages in this area. Orientation of the gossan measured is N30E. Limonitization and hematitization are very marked along this gossan (Figure 12).
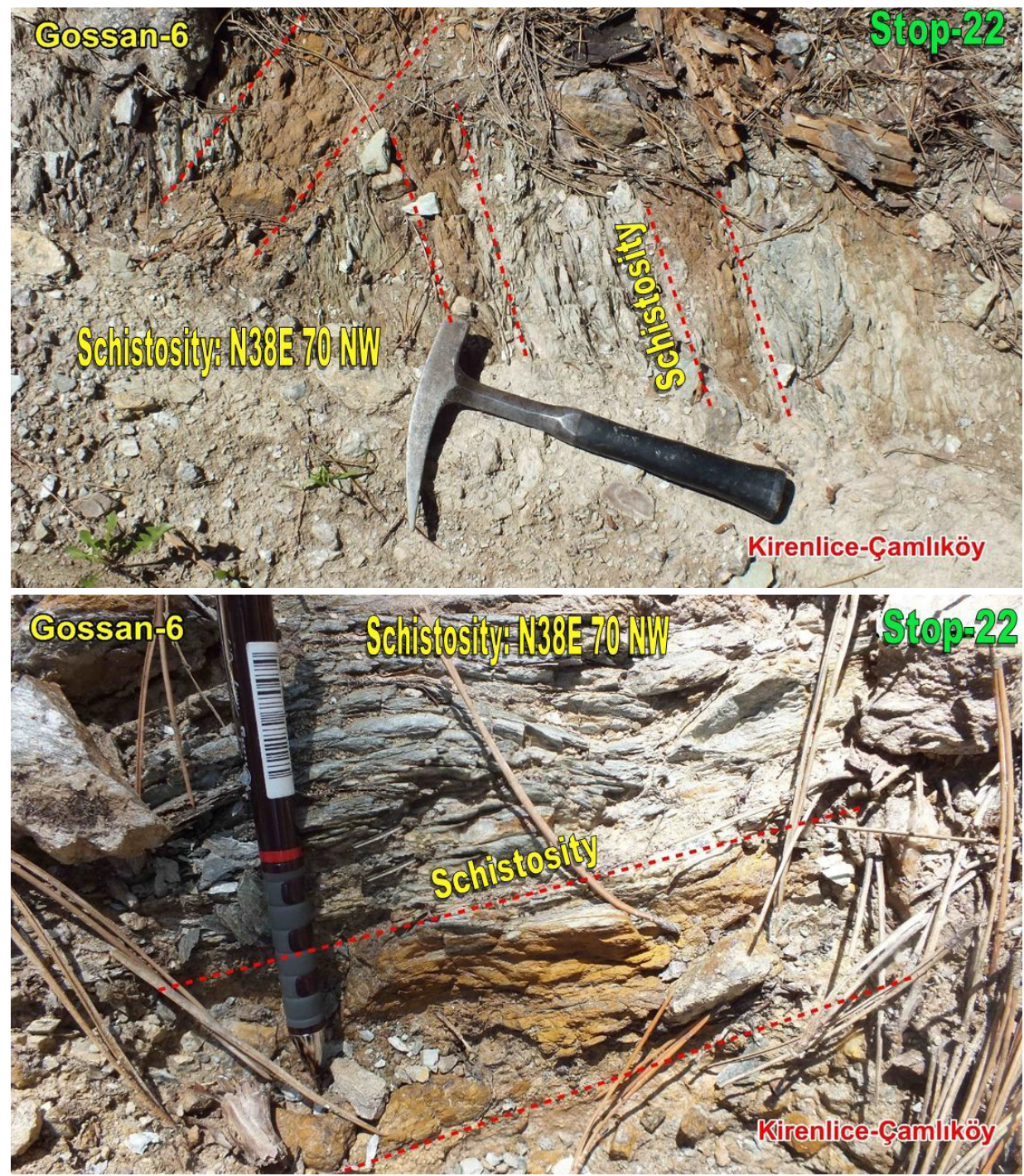

Figure 11: Gossan-6 formed concordantly with schistosity and close to the contact of metamorphics of Akgöl Formation and ophiolites of Elekdağ near Kirenlice-Çamlıköy. 

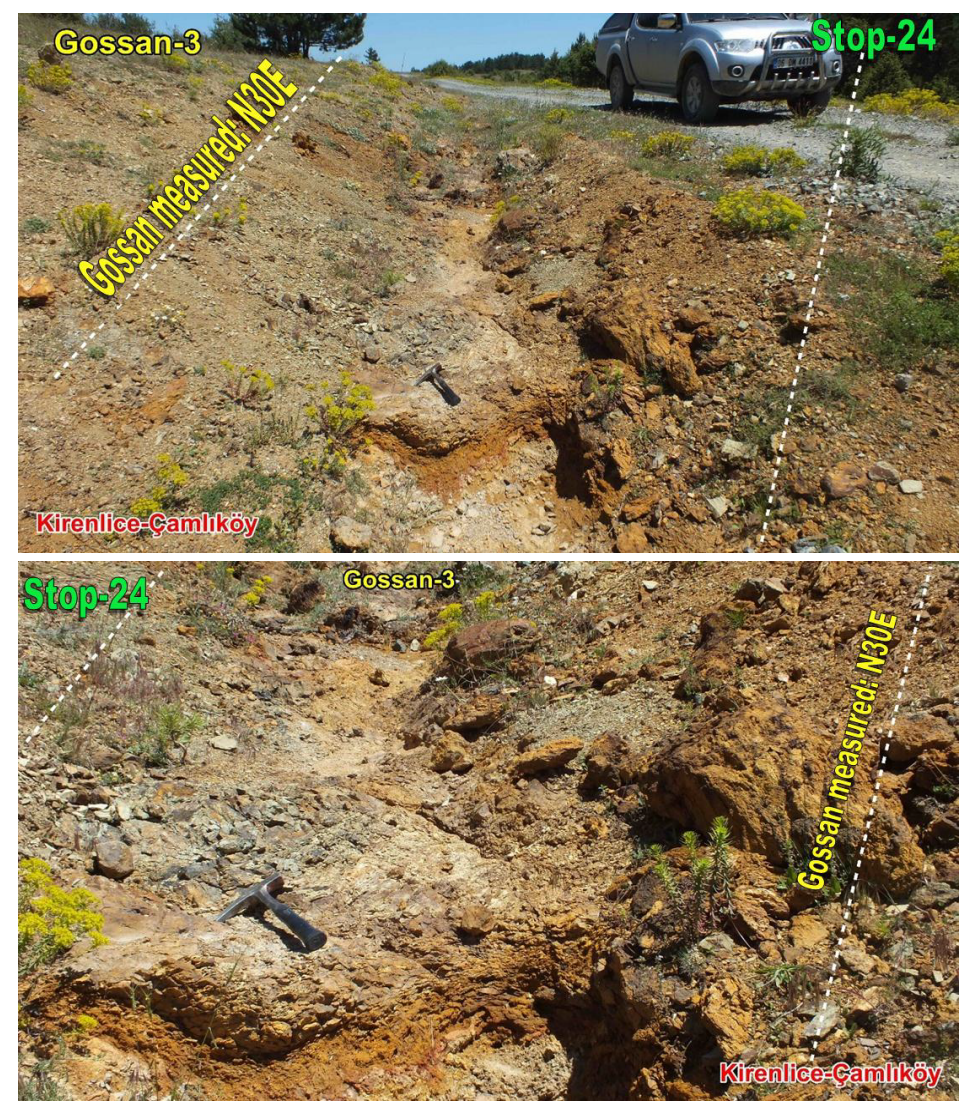

Figure 12: NE-SW-orientation Gossan-3 formed close to the contact of metamorphics of Akgöl Formation and ophiolites of Elekdağ near Kirlenice-Çamlıköy.

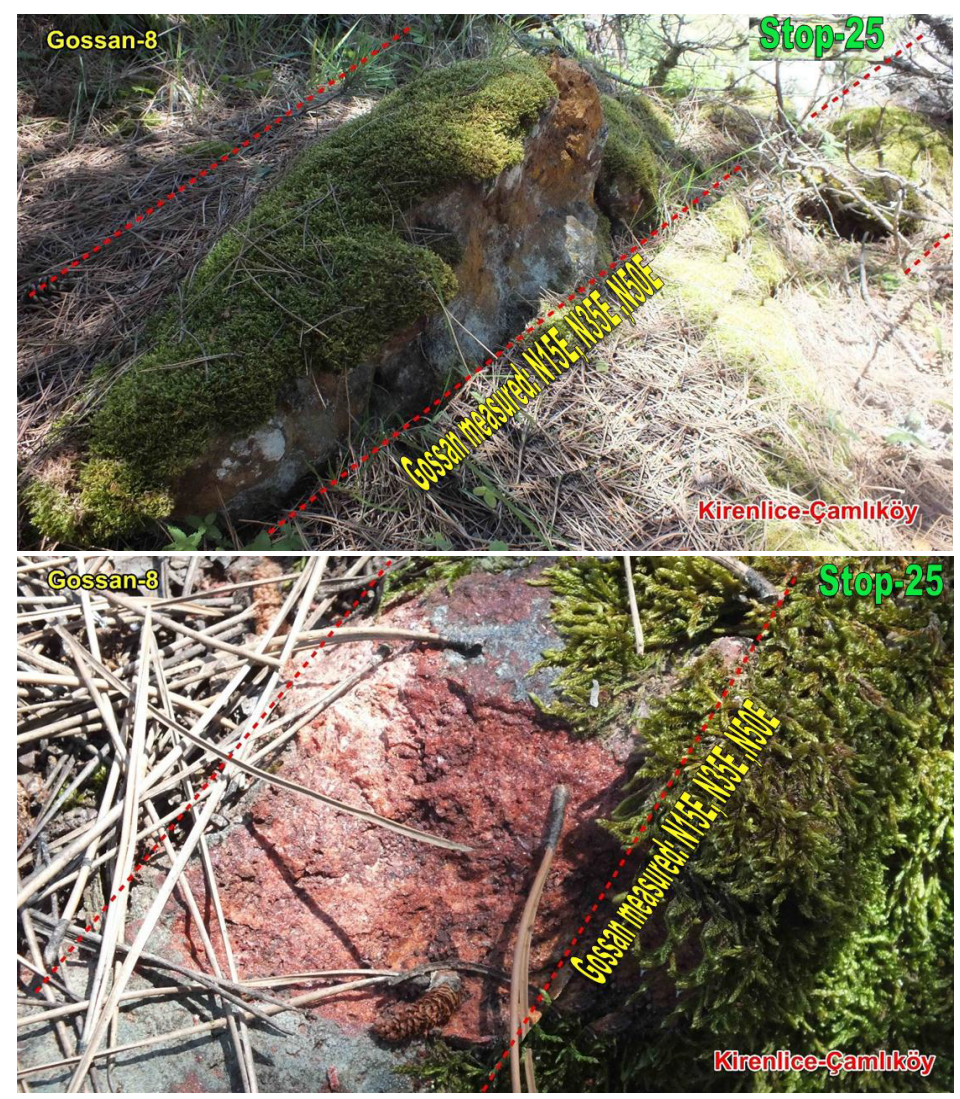

Figure 13: NE-SW-orientation Gossan-8 formed in stages and close to the contact of metamorphics of Akgöl Formation and ophiolites of Elekdağ near Kirenlice-Çamlıköy. 

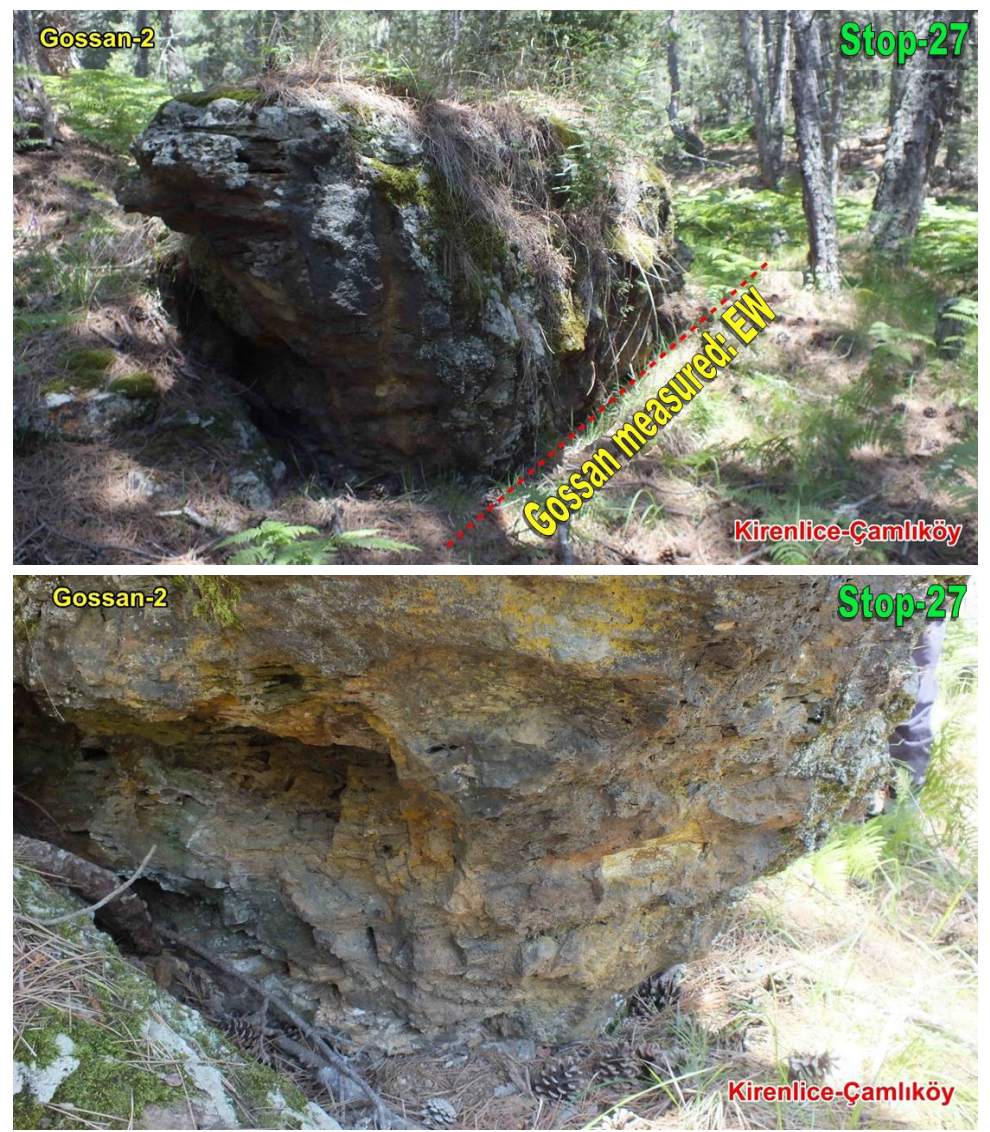

Figure 14: E-W-orientation Gossan-2 formed in stages and close to the contact of metamorphics of Akgöl Formation and ophiolites of Elekdağ near Kirenlice-Çamlıköy.
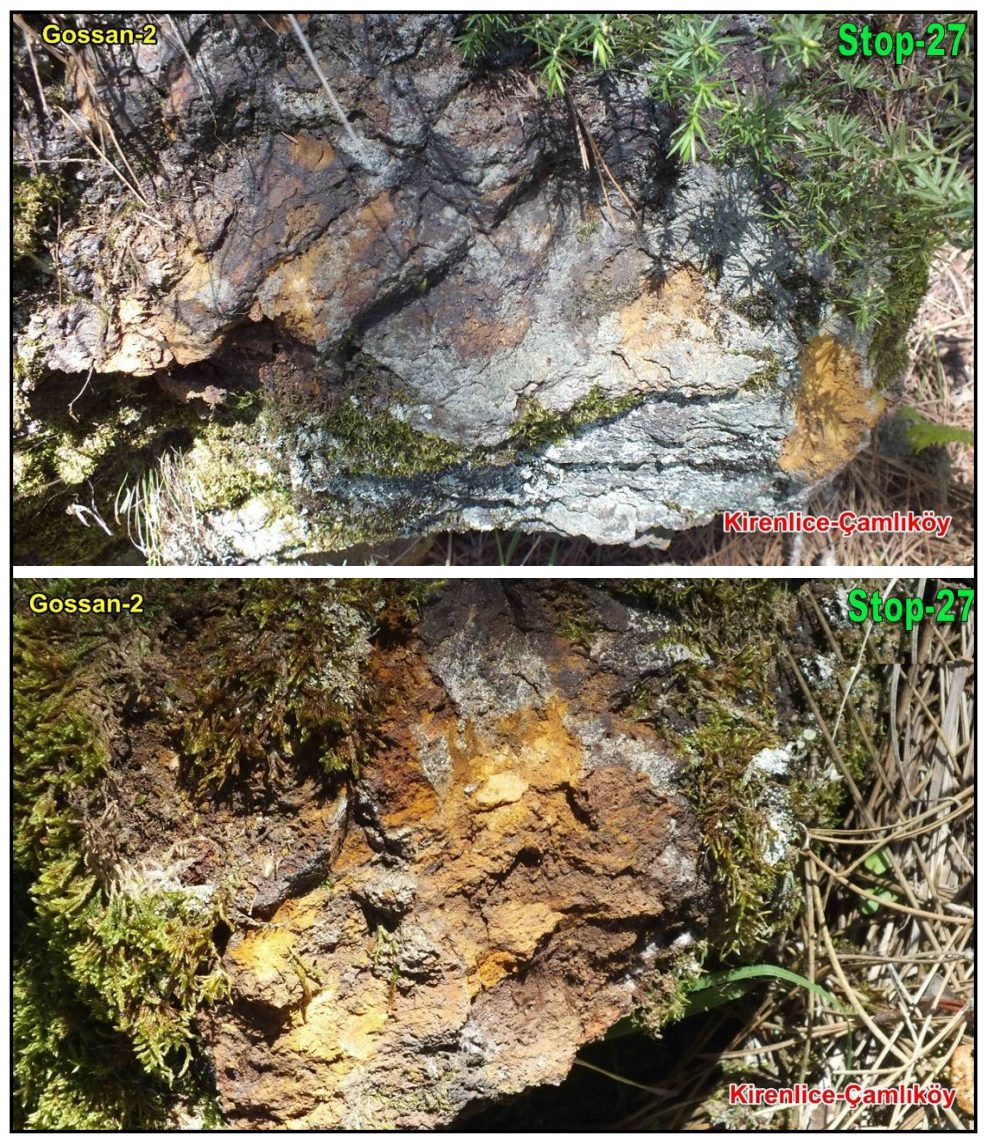

Figure 15: Close view of E-W-orientation Gossan-2 formed in stages and close to the contact of metamorphics of Akgöl Formation and ophiolites of Elekdağ near Kirenlice-Çamlıköy.

Citation: Ozdemir A, Sahinoglu A (2018) Important of Gossans in Mineral Exploration: A Case Study in Northern Turkey. Int J Earth Sci Geophys 4:019 
Gossan- 8 is located on the eastern slope of Bestici hill between Çamlıköy and Kirenlice. This gossan has a number of caps appearing in several stages. Staged orientation of caps measured is N15E, N35E and N50E respectively. Limonitization and hematitization are very marked along these caps (Figure 13).

Gossan-2 is located approximately $1250 \mathrm{~m}$ in the south of Çamlıköy between Çamlıköy and Kirenlice. Orientation of this gossan measured is EW. The gossan is within metamorphics of Akgöl Formation. $1 \mathrm{~km}$ to the south exists Elekdağı thrusting. Limonitization and hematitization are very marked along this gossan (Figure 14 and Figure 15).

\section{Geochemical Studies}

Detailed geochemical surveys were performed to the south of gossans on the study area. Samples of rocks and stream sediments were collected and these samples were analyzed at ALS laboratories. Samples of rocks and stream sediments were collected by Gentor Resources Limited where necessary and these samples were analyzed at ALS laboratory (Turkey Branch) using OlympusInnov-X Delta 50 portable XRF. No samples were collected for soil chemistry and analyses were performed on the site. Table 1 shows the analysis results of chip samples from gossans. Au is present in some analysis results of chip samples from gossans. XRF is sensitive to other metals rather than Au. It shows the presence of $\mathrm{Au}$ in samples that contain Au. However, the Au value does not exactly reflect the reality. The readout was 111 ppm of Au with Au value in the gossans containing malachite cover. Figure 16 shows the location of samples of which 6012 and 6013 contain gold. Gossans located in the southwest have a higher $\mathrm{Cu}$ value compared to gossans in the southeast. Except for a sample collected from gossans in the northeast, remaining samples do not have lead anomaly. Samples collected from gossans in the southwest have a zinc anomaly. The presence of cobalt is a significant indicator of a VMS-type mineralization.

Table 1: Analysis results of chip samples (Values is ppm).

\begin{tabular}{|c|c|c|c|c|c|c|c|c|c|c|c|c|c|c|}
\hline $\begin{array}{l}\text { Sample } \\
\text { Ticket No }\end{array}$ & WPN & Easting & Norting & $\#$ & As & $\mathrm{Ag}$ & $\mathrm{Au}$ & $\mathrm{Cu}$ & $\mathrm{Pb}$ & $\mathrm{Zn}$ & Co & Sb & $\mathrm{Hg}$ & Sn \\
\hline 4950 & 101 & 631840 & 4604642 & 4950 & 22.9 & 1.5 & ND & 1690.0 & 8.6 & 325.0 & 127.0 & 1 & 3.18 & 5.7 \\
\hline \multirow{6}{*}{6012} & \multirow{6}{*}{3547} & \multirow{6}{*}{633012} & \multirow{6}{*}{4605477} & $\# 41$ & 17.5 & ND & ND & 3123.0 & ND & 297.0 & 22.0 & ND & ND & 43 \\
\hline & & & & \#42 & 59.0 & ND & ND & 4136.0 & 189 & 328.0 & ND & ND & ND & 61 \\
\hline & & & & \#43 & ND & 111.0 & 18.0 & 3635.0 & 2965 & 661.0 & 184.0 & ND & ND & 75 \\
\hline & & & & $\# 44$ & 103.0 & ND & ND & 3411.0 & ND & 198.0 & 114.0 & ND & ND & 61 \\
\hline & & & & $\# 45$ & 286.0 & ND & ND & 4825.0 & ND & 340.0 & 243.0 & ND & ND & 61 \\
\hline & & & & $\# 46$ & 80.0 & ND & ND & 2261.0 & ND & 174.0 & 214.0 & ND & ND & 62 \\
\hline \multirow{6}{*}{6013} & \multirow{6}{*}{3539} & \multirow{6}{*}{632844} & \multirow{6}{*}{4605226} & $\# 47$ & 25.0 & ND & ND & 816.0 & ND & 25.0 & 73.0 & ND & ND & ND \\
\hline & & & & $\# 48$ & 83.0 & ND & ND & 956.0 & ND & 73.0 & 73.0 & ND & ND & ND \\
\hline & & & & $\# 49$ & 85.0 & ND & ND & 506.0 & ND & ND & ND & ND & ND & 72 \\
\hline & & & & $\# 51$ & 28.0 & ND & ND & 1030.0 & ND & ND & 94.0 & ND & ND & ND \\
\hline & & & & $\# 52$ & 32.0 & ND & ND & 2204.0 & ND & ND & 109.0 & ND & ND & 86 \\
\hline & & & & \#53 & ND & ND & 22.0 & 1275.0 & 618 & ND & 245.0 & ND & ND & 69 \\
\hline \multirow{7}{*}{6014} & \multirow{7}{*}{3548} & \multirow{7}{*}{632989} & \multirow{7}{*}{4605442} & \#54 & ND & ND & ND & 712.0 & 339 & 356.0 & 27.0 & ND & 29 & 165 \\
\hline & & & & \#55 & 48.0 & ND & ND & 3370.0 & 50 & 638.0 & ND & ND & 16 & ND \\
\hline & & & & \#56 & 20.1 & ND & ND & 1248.0 & ND & 221.0 & ND & ND & 9 & ND \\
\hline & & & & \#58 & 11.2 & ND & ND & 963.0 & ND & 390.0 & 17.0 & ND & 11 & ND \\
\hline & & & & \#59 & 49.0 & ND & ND & 2649.0 & ND & 546.0 & 100.0 & ND & 19 & 113 \\
\hline & & & & \#60 & 35.0 & ND & ND & 2925.0 & ND & 328.0 & ND & ND & 13 & ND \\
\hline & & & & \#61 & 9.0 & ND & ND & 41102.0 & ND & 1763.0 & 86.0 & ND & ND & 43 \\
\hline \multirow[t]{7}{*}{6015} & \multirow[t]{7}{*}{3568} & \multirow[t]{7}{*}{632129} & \multirow[t]{7}{*}{4604743} & \#62 & 18.0 & ND & ND & 394.0 & ND & ND & 73.0 & ND & ND & ND \\
\hline & & & & \#63 & 51.0 & ND & ND & 556.0 & ND & 196.0 & ND & ND & ND & ND \\
\hline & & & & $\# 64$ & 15.0 & ND & ND & 423.0 & 27 & 505.0 & 102.0 & ND & ND & ND \\
\hline & & & & \#65 & 27.0 & ND & ND & 544.0 & ND & 1277.0 & 131.0 & ND & ND & ND \\
\hline & & & & \#66 & 95.0 & ND & ND & 645.0 & ND & ND & ND & ND & ND & ND \\
\hline & & & & \#68 & 58.0 & ND & ND & 641.0 & ND & 1734.0 & 224.0 & ND & ND & ND \\
\hline & & & & \#69 & 10.0 & ND & ND & 332.0 & ND & 21.0 & 92.0 & ND & ND & ND \\
\hline \multirow{6}{*}{6016} & \multirow{6}{*}{3569} & \multirow{6}{*}{632160} & \multirow{6}{*}{4604743} & $\# 70$ & 10.0 & ND & ND & 376.0 & ND & ND & ND & ND & ND & ND \\
\hline & & & & \#71 & 42.0 & ND & ND & 1012.0 & ND & ND & 113.0 & ND & ND & ND \\
\hline & & & & $\# 72$ & ND & ND & ND & 225.0 & 332 & 88.0 & 74.0 & ND & ND & ND \\
\hline & & & & \#73 & 87.0 & ND & ND & 536.0 & ND & ND & 415 & ND & ND & ND \\
\hline & & & & $\# 74$ & 16.0 & ND & ND & 328.0 & ND & ND & ND & ND & ND & ND \\
\hline & & & & \#76 & 34.0 & ND & ND & 185.0 & ND & ND & 65 & ND & ND & 46 \\
\hline
\end{tabular}

ND: Not Detectable 


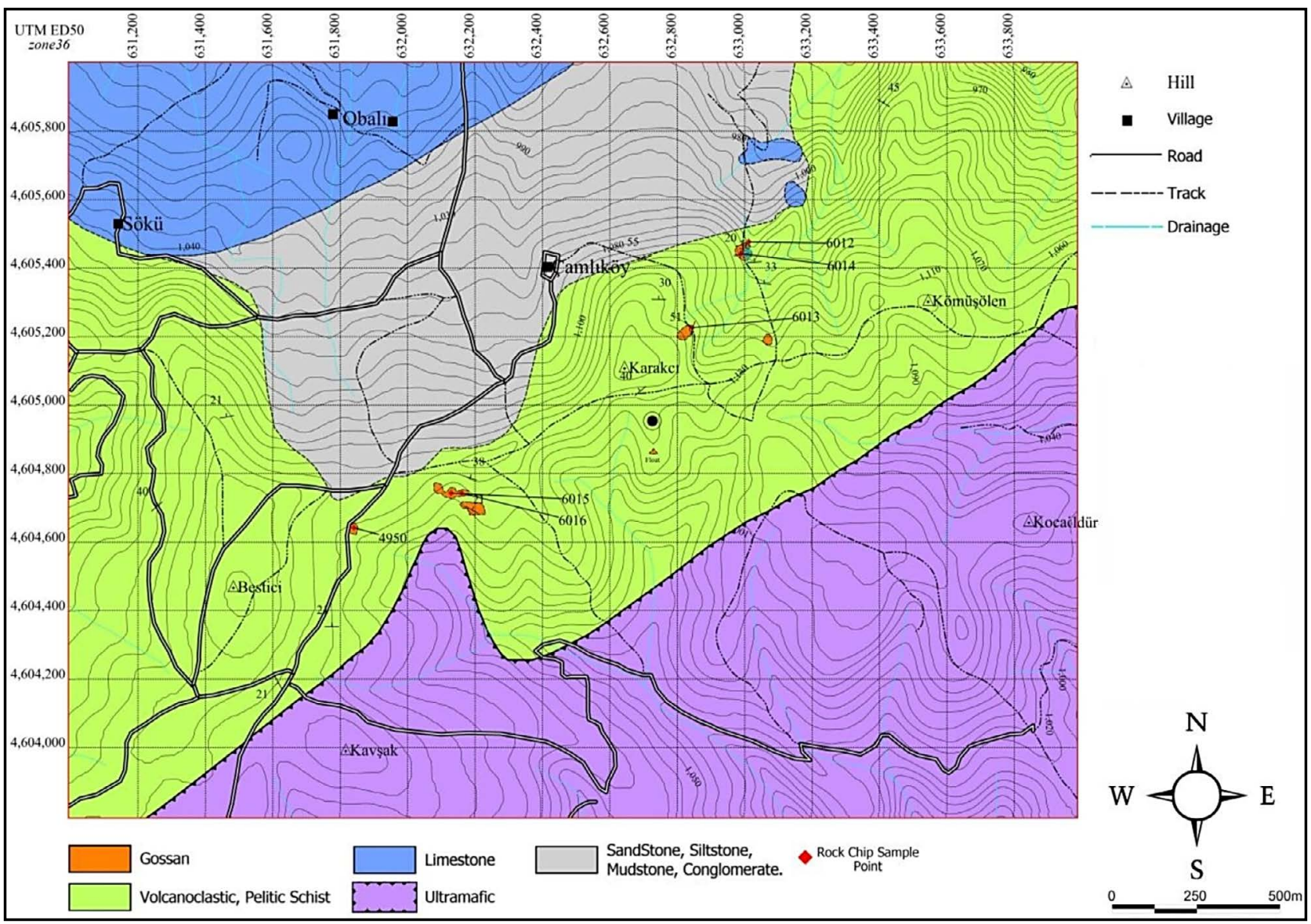

Figure 16: Location of rock chip samples on the geology map.

Table 2: Analysis results of stream sediment (Values is ppm).

\begin{tabular}{|c|c|c|c|c|c|c|c|c|c|c|c|c|c|c|}
\hline $\begin{array}{l}\text { Sample } \\
\text { Ticket No }\end{array}$ & WPN & Easting & Northing & $\begin{array}{l}\text { Reading } \\
\text { No }\end{array}$ & As & $\mathrm{Ag}$ & $\mathrm{Au}$ & $\mathrm{Cu}$ & $\mathbf{P b}$ & $\mathrm{Zn}$ & Co & Sb & $\mathrm{Hg}$ & Sn \\
\hline 6053 & 4229 & 633284 & 4605687 & 2 & 6.3 & ND & ND & 84.0 & 4.3 & 84.0 & 24.2 & ND & ND & 31 \\
\hline 6054 & 4230 & 633198 & 4605485 & 4 & 31.8 & ND & ND & 98.0 & 38.6 & 96.0 & 21.4 & ND & ND & ND \\
\hline 6055 & 4231 & 632960 & 4604489 & 6 & 18.5 & ND & ND & 63.0 & 9 & 58.1 & 17.1 & ND & ND & ND \\
\hline 6056 & 4232 & 633428 & 4603932 & 8 & ND & ND & ND & 29.0 & 7.3 & 43.1 & 35.1 & ND & ND & ND \\
\hline 6057 & 4233 & 633418 & 4603917 & 10 & ND & ND & ND & 22.0 & 7.9 & 49.6 & 32.7 & ND & ND & ND \\
\hline 6058 & 4234 & 633767 & 4604917 & 12 & 6.8 & ND & ND & 35.0 & 11.4 & 45.0 & 25.1 & ND & ND & ND \\
\hline 6059 & 4235 & 632371 & 4604334 & 14 & ND & ND & ND & 14.0 & 4 & 36.7 & 26.5 & ND & ND & ND \\
\hline 6060 & 4263 & 632327 & 4604330 & 16 & ND & ND & ND & 28.0 & 3.5 & 24.2 & 6.8 & ND & ND & ND \\
\hline
\end{tabular}

ND: Not Detectable

Samples of stream sediment collected with -80-mesh sieve were analyzed and analyses results are presented in Table 2. No anomalies were observed in samples of stream sediment as presented in Figure 17 by their location.

Based on results of analyses performed on the site, Figure 18, Figure 19 and Figure 20 show thematic geology maps of soil together with results of other analyses. Although a general anomaly was observed around the gossans, it cannot be interpreted as a strong anomaly as it is near the local threshold value. Soil geochemistry is usually very effective in searching for VMS. The highest value of $270 \mathrm{ppm}$ for $\mathrm{Cu}$ indicates a poor soil geochemistry. The anomaly of $\mathrm{Zn}$ is not what was expected.
A limited number and depth of boreholes were made to exploration for massive sulfide ores in study area, and laboratory analyses were performed on core samples (Figure 21, Figure 22 and Table 3).

\section{Conclusions}

Two marked types of gossans within study area are greyish red, heavy, massive limonite and light red, light and poorly porous limonite. Both of these two types are usually very hard and display local brecciated structures. The size of pieces of breccia is average $5 \mathrm{~cm}$ and pieces are either composed of locally earthy limonite with goethite or of fine grain quartz. They are placed in limonite matrix with some secondary quartz. There are 8 gos- 


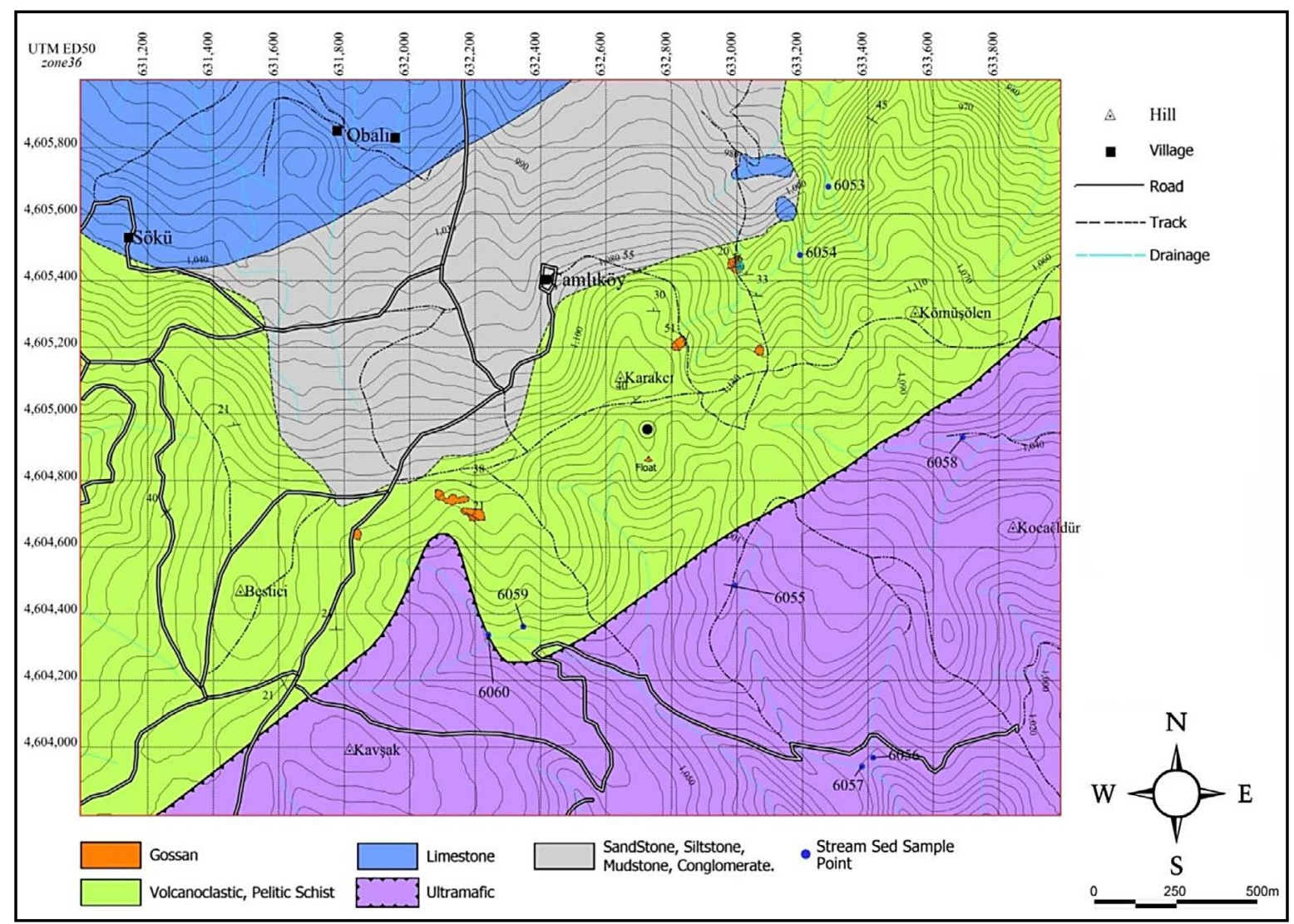

Figure 17: Location of stream sediment samples on the geology map.

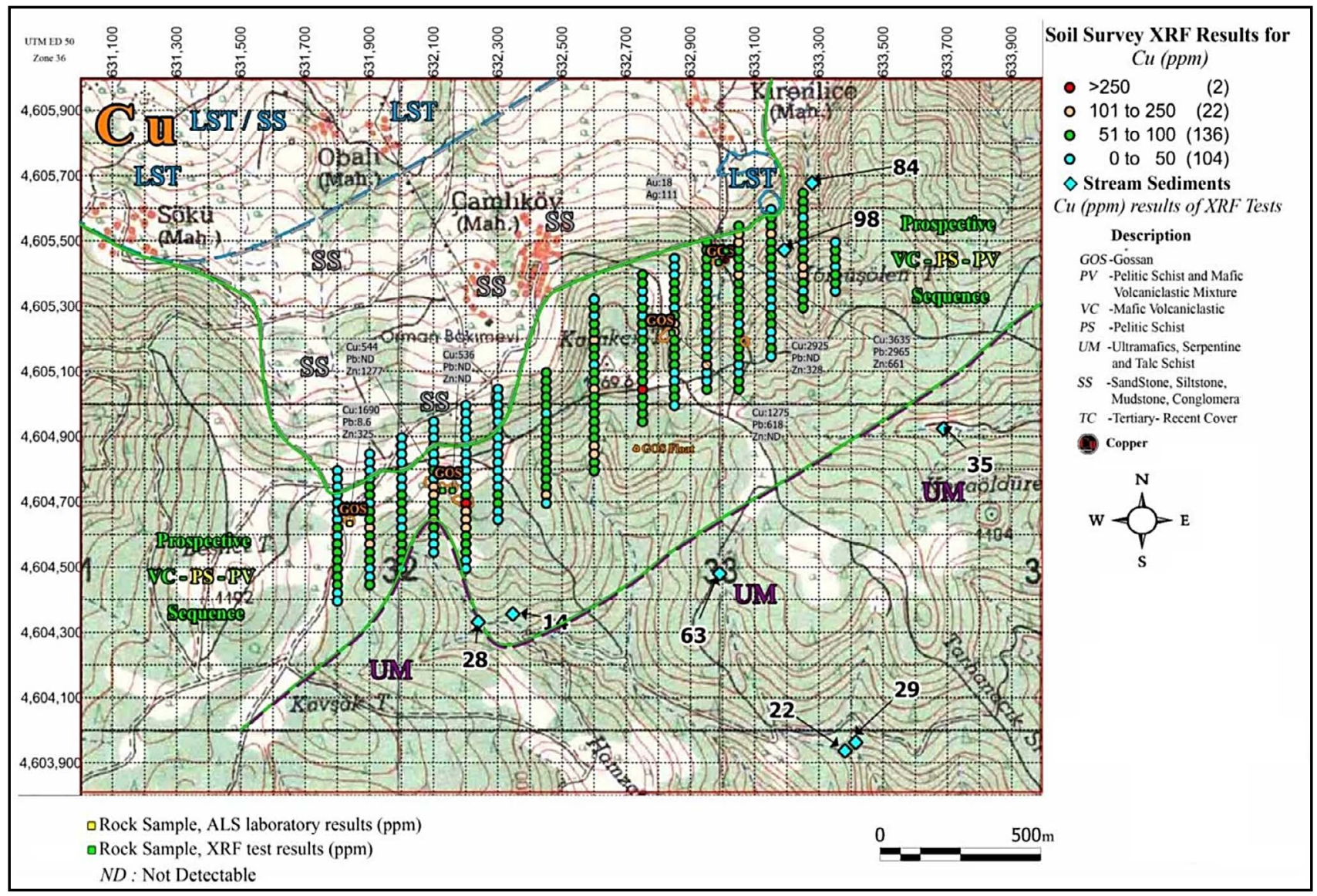

Figure 18: Soil geochemistry - Cu. 


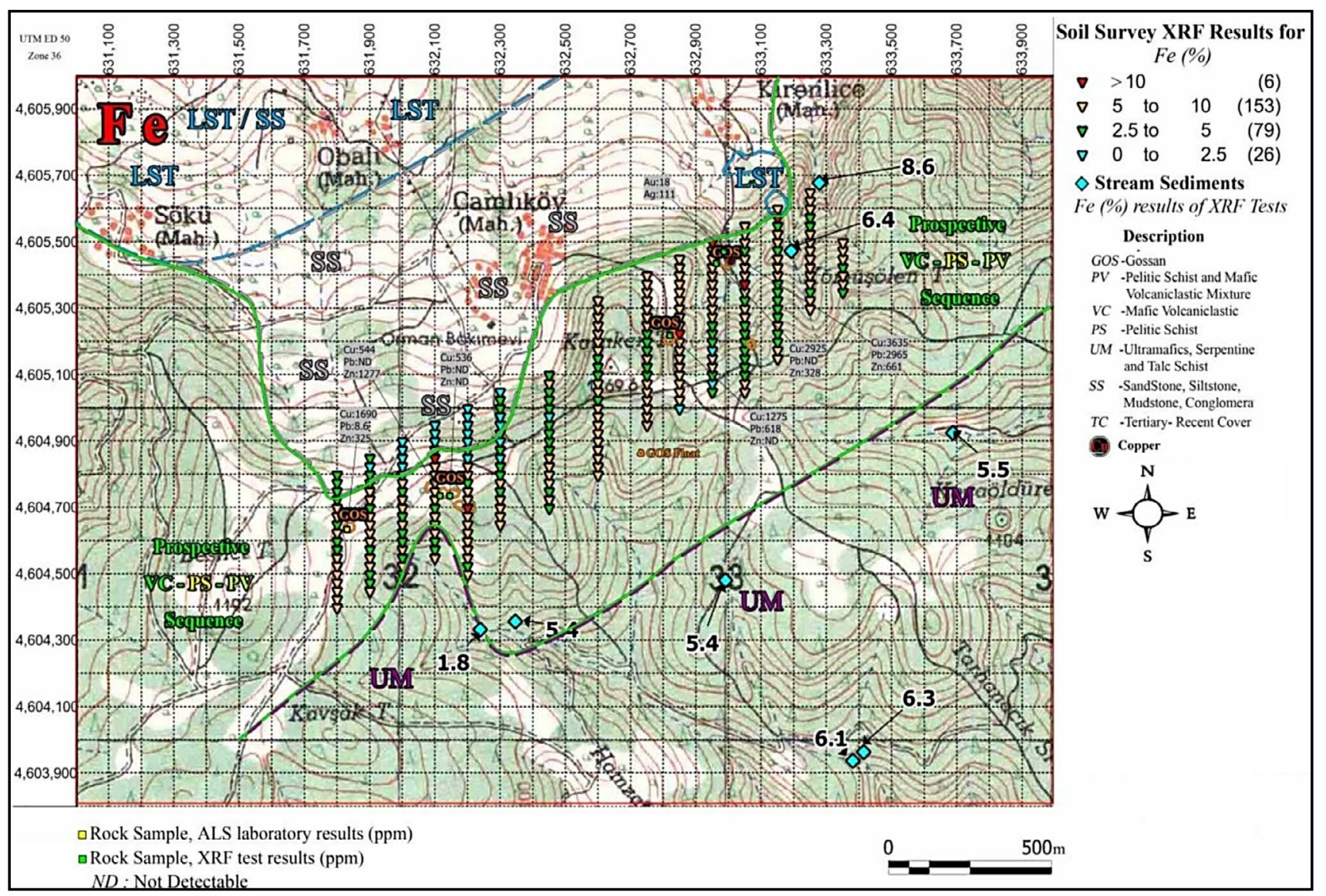

Figure 19: Soil geochemistry - Fe.

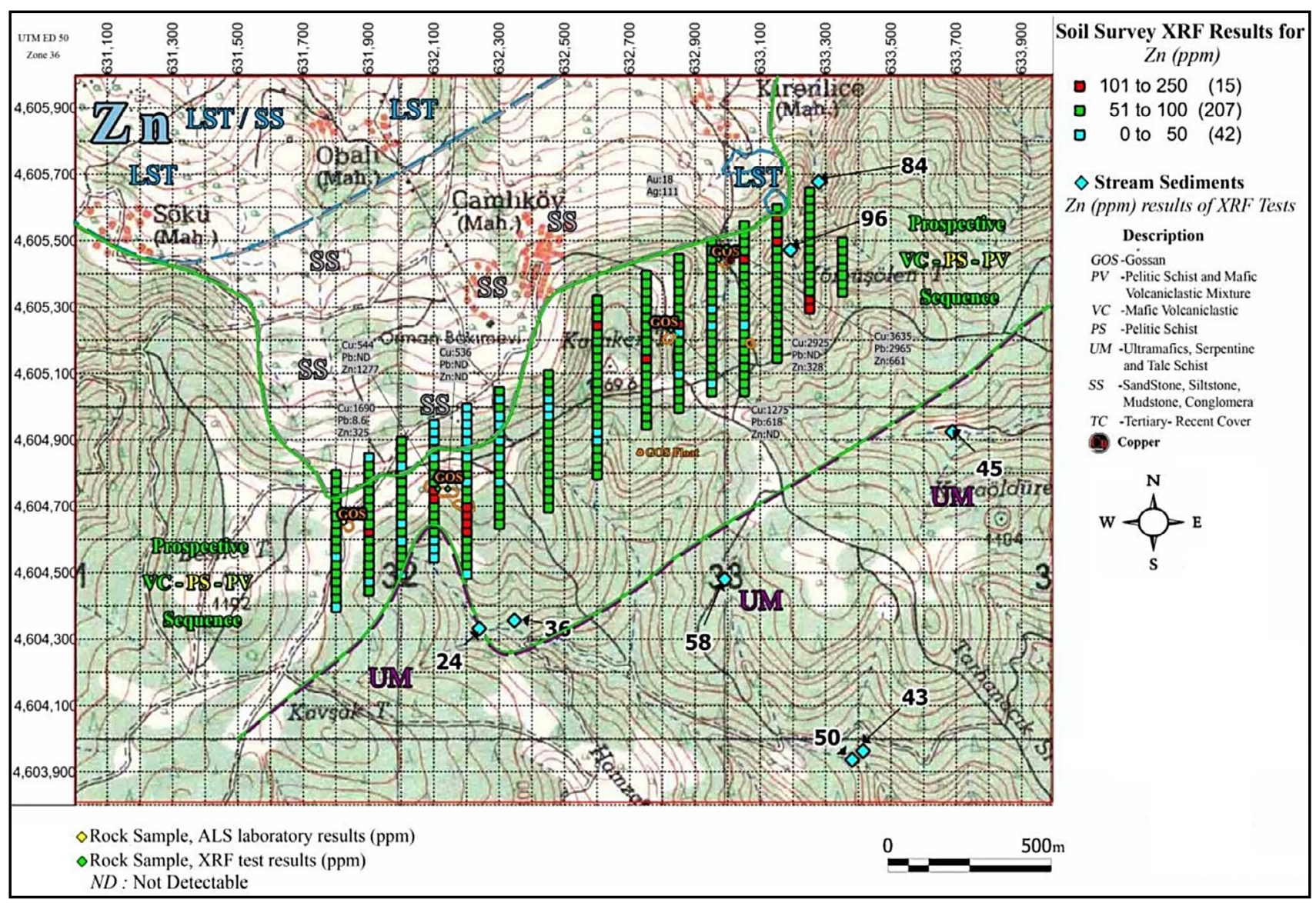

Figure 20: Soil geochemistry - Zn. 


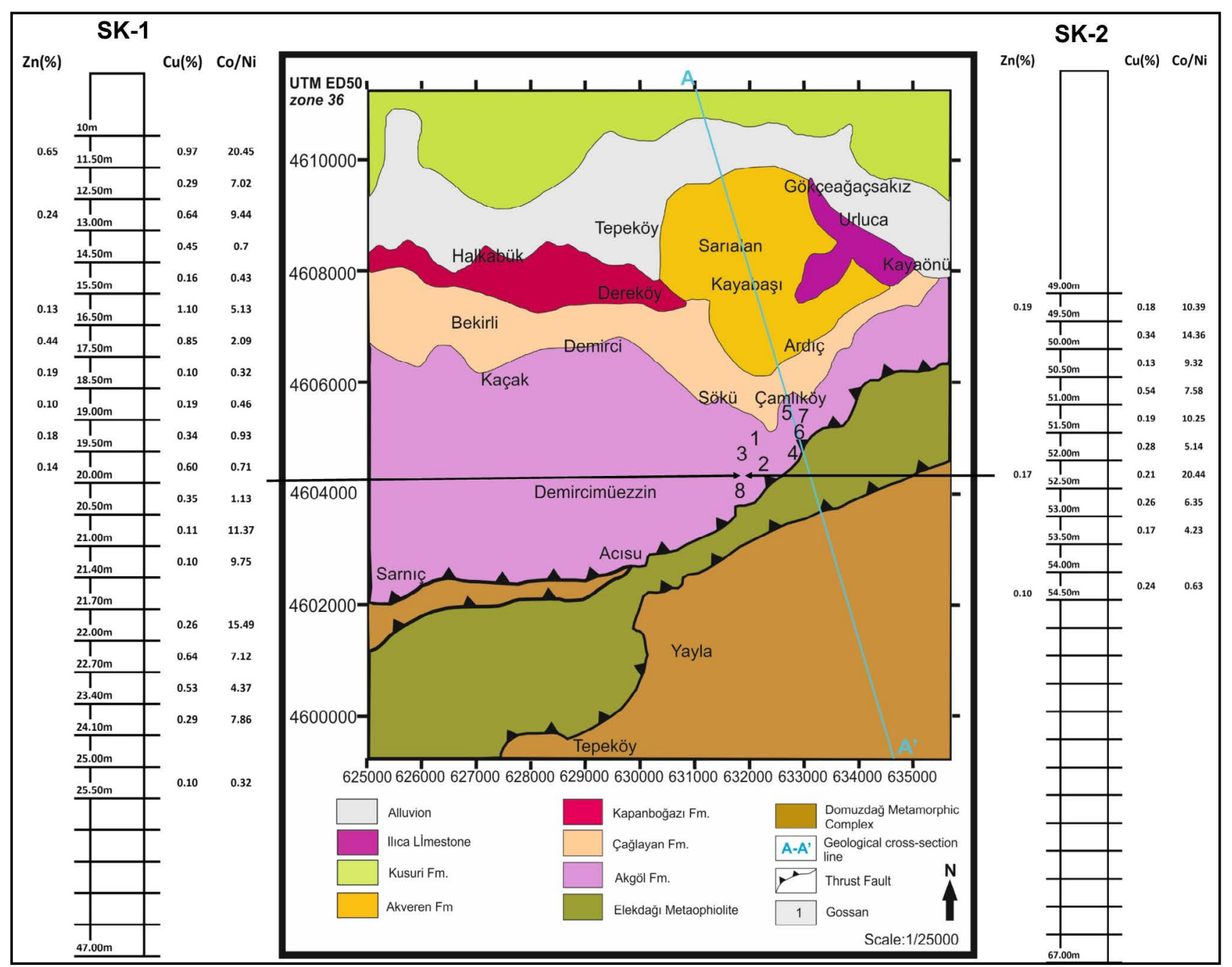

Figure 21: Analysis results of core samples.

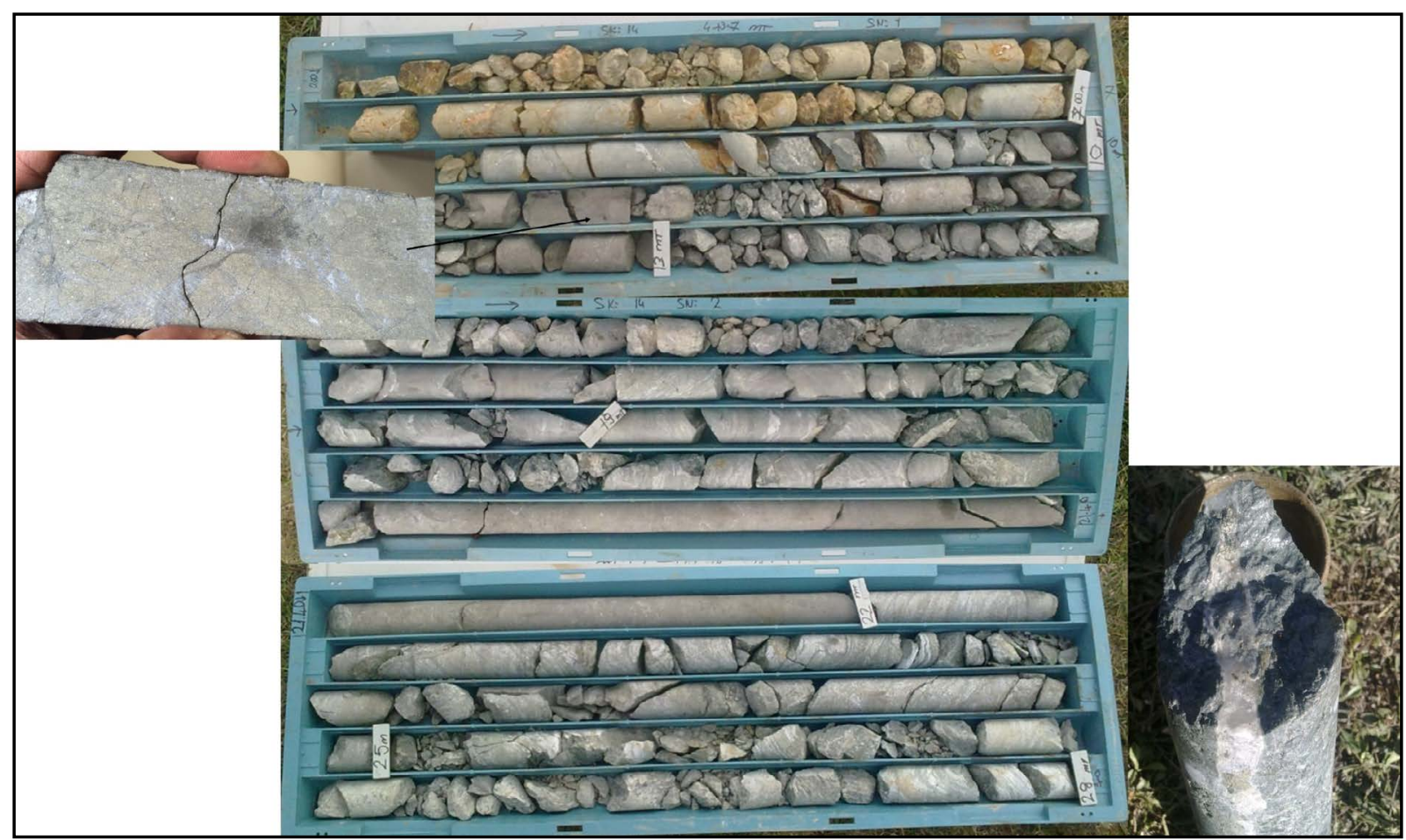

Figure 22: Core samples of massive sulfide ores in study area. 
Table 3: Analysis results of core samples of massive sulfide ores in study area.

\begin{tabular}{|c|c|c|c|c|c|c|c|c|c|c|c|c|c|}
\hline \multirow{2}{*}{$\begin{array}{l}\text { Borehole } \\
\text { No }\end{array}$} & \multirow[t]{2}{*}{ Interval (m) } & \multirow{2}{*}{$\begin{array}{l}\mathrm{Cu} \\
\%\end{array}$} & \multirow{2}{*}{$\begin{array}{l}Z n \\
\%\end{array}$} & \multirow{2}{*}{$\begin{array}{l}\text { Pb } \\
\text { ppm }\end{array}$} & \multirow{2}{*}{$\begin{array}{l}\text { Au } \\
\text { ppm }\end{array}$} & \multirow{2}{*}{$\begin{array}{l}\text { Ag } \\
\text { ppm }\end{array}$} & \multirow{2}{*}{$\begin{array}{l}\text { Co } \\
\text { ppm }\end{array}$} & \multirow{2}{*}{$\begin{array}{l}\mathrm{Ni} \\
\mathrm{ppm}\end{array}$} & \multirow{2}{*}{$\begin{array}{l}\text { As } \\
\text { ppm }\end{array}$} & \multirow{2}{*}{$\begin{array}{l}\text { Mo } \\
\text { ppm }\end{array}$} & \multirow{2}{*}{$\begin{array}{l}\text { Sb } \\
\text { ppm }\end{array}$} & \multirow{2}{*}{$\begin{array}{l}\text { Ti } \\
\text { ppm }\end{array}$} & \multirow[t]{2}{*}{$\mathrm{Co} / \mathrm{Ni}$} \\
\hline & & & & & & & & & & & & & \\
\hline \multirow{20}{*}{ SK-1 } & $10.00-11.50$ & 0.97 & 0.65 & 45 & $<0.15$ & 2 & 593 & 29 & 39 & 22 & 12 & 82 & 20.45 \\
\hline & $11.50-12.50$ & 0.29 & 337 ppm & 31 & $<0.15$ & 1 & 435 & 62 & 38 & 2 & 9 & 185 & 7.02 \\
\hline & $12.50-13.00$ & 0.64 & 0.24 & 252 & $<0.15$ & 5 & 472 & 50 & 41 & 19 & 12 & 101 & 9.44 \\
\hline & $13.00-14.50$ & 0.45 & 516 ppm & 22 & $<0.15$ & 4 & 56 & 80 & 41 & 2 & $<5$ & 153 & 0.7 \\
\hline & $14.50-15.50$ & 0.16 & 169 ppm & 40 & $<0.15$ & 5 & 20 & 46 & 34 & $<1$ & 5 & 55 & 0.43 \\
\hline & $15.50-16.50$ & 1.10 & 0.13 & 55 & $<0.15$ & 1 & 231 & 45 & 52 & 11 & 7 & 46 & 5.13 \\
\hline & $16.50-17.50$ & 0.85 & 0.44 & 207 & $<0.15$ & 2 & 165 & 79 & 78 & 9 & 6 & 267 & 2.09 \\
\hline & $17.50-18.50$ & 0.1 & 0.19 & 42 & $<0.15$ & $<0.15$ & 53 & 166 & 47 & $<1$ & 1 & 429 & 0.32 \\
\hline & $18.50-19.00$ & 0.19 & 0.10 & 20 & $<0.15$ & 1 & 71 & 154 & 45 & $<1$ & $<5$ & 795 & 0.46 \\
\hline & $19.00-19.50$ & 0.34 & 0.18 & 17 & $<0.15$ & $<0.15$ & 107 & 115 & 37 & 1 & $<5$ & 874 & 0.93 \\
\hline & $19.50-20.00$ & 0.60 & 0.14 & 16 & $<0.15$ & 3 & 84 & 118 & 57 & $<1$ & $<5$ & 229 & 0.71 \\
\hline & $20.00-20.50$ & 0.35 & 710 ppm & 16 & $<0.15$ & 2 & 76 & 67 & 72 & 2 & 9 & 105 & 1.13 \\
\hline & $20.50-21.00$ & 0.11 & 510 ppm & 16 & $<0.15$ & 4 & 557 & 49 & 34 & 2 & 5 & 108 & 11.37 \\
\hline & $21.00-21.40$ & 0.1 & 710 ppm & 21 & $<0.15$ & 4 & 585 & 60 & 57 & 2 & 6 & 120 & 9.75 \\
\hline & $21.40-21.70$ & 0.1 & 810 ppm & 11 & $<0.15$ & 4 & 0.11 & 46 & 69 & 2 & 5 & 73 & 23.90 \\
\hline & $21.70-22.00$ & 0.26 & 510 ppm & 27 & $<0.15$ & 3 & 697 & 45 & 75 & 3 & 5 & 103 & 15.49 \\
\hline & $22.00-22.70$ & 0.64 & 33 ppm & $<2$ & $<0.15$ & 4 & 406 & 57 & 68 & 2 & $<5$ & 105 & 7.12 \\
\hline & $22.70-23.40$ & 0.53 & 544 ppm & 17 & $<0.15$ & 3 & 214 & 49 & 70 & 3 & $<5$ & 96 & 4.37 \\
\hline & $23.40-24.10$ & 0.29 & 419 ppm & 10 & $<0.15$ & 3 & 448 & 57 & 29 & 2 & 7 & 141 & 7.86 \\
\hline & $25.00-25.50$ & 0.1 & 649 ppm & 131 & $<0.15$ & 3 & 29 & 90 & 80 & 3 & 18 & 197 & 0.32 \\
\hline \multirow{10}{*}{ SK-2 } & $49.00-49.50$ & 0.18 & 0.19 & 27 & $<0.15$ & 6 & 509 & 49 & 86 & 1 & 41 & 100 & 10.39 \\
\hline & $49.50-50.00$ & 0.34 & 33 ppm & 32 & $<0.15$ & $<0.15$ & 675 & 47 & 10 & 3 & 10 & 67 & 14.36 \\
\hline & $50.00-50.50$ & 0.13 & $<10 \mathrm{ppm}$ & 20 & $<0.15$ & $<0.15$ & 605 & 61 & 32 & 14 & 10 & 118 & 9.92 \\
\hline & $50.50-51.00$ & 0.54 & 13 ppm & 27 & $<0.15$ & $<0.15$ & 379 & 50 & 10 & 3 & 22 & 87 & 7.58 \\
\hline & $51.00-51.50$ & 0.19 & 181 ppm & 20 & $<0.15$ & $<0.15$ & 410 & 40 & 27 & 3 & 30 & 85 & 10.25 \\
\hline & $51.50-52.00$ & 0.28 & 195 ppm & 23 & $<0.15$ & $<0.15$ & 252 & 49 & 35 & 3 & 33 & 90 & 5.14 \\
\hline & $52.00-52.50$ & 0.21 & 0.17 & 23 & $<0.15$ & $<0.15$ & 797 & 39 & 30 & 32 & 37 & 112 & 20.44 \\
\hline & $52.50-53.00$ & 0.26 & 460 ppm & 19 & $<0.15$ & $<0.15$ & 330 & 52 & 37 & 2 & 41 & 121 & 6.35 \\
\hline & $53.00-53.50$ & 0.17 & 143 ppm & 20 & $<0.15$ & $<0.15$ & 241 & 57 & 54 & 2 & 39 & 131 & 4.23 \\
\hline & $54.00-54.50$ & 0.24 & 936 ppm & 13 & $<0.15$ & $<0.15$ & 50 & 79 & 35 & 2 & 42 & 240 & 0.63 \\
\hline
\end{tabular}

sans outcrops in NE-SW orientation in the area of 1.6 $\mathrm{km}$ in length among units targeted for mineralization. The presence of these gossans indicates that here may be mineralization within the study area. Detailed geochemical surveys were performed to the south of gossans on the study area. Gossans located in the southwest have a higher $\mathrm{Cu}$ value compared to gossans in the southeast. Except for a sample collected from gossans in the northeast, remaining samples do not have lead anomaly. Samples collected from gossans in the southwest have a zinc anomaly. The presence of cobalt is a significant indicator of a VMS-type mineralization. In the study area and surroundings, metamorphic units of pelitic schist, mafic volcanoclastic targeted for VMS-type mineralization and thrusting ultramafic rocks are located to the south of study area.

\section{References}

1. Özdemir A (2015) Exploration Studies of Hanönü-Boyabat Mine Sites, 215.

2. Yılmaz Y, Tüysüz O (1984) Kastamonu-Boyabat-Vezirköprü-Tosya arasındaki bölgenin jeolojisi (Ilgaz-Kargı Masiflerinin Etüdü). General Directorate of Mineral Research and Exploration of Turkey, Report No. 7838.
3. Sütçü YF, Barkurt MY, Bilginer E, Kurt Z, Pehlivan Ş (1994) Boyabat-Vezirköprü arasının jeolojisi. General Directorate of Mineral Research and Exploration of Turkey, Report No. 9884.

4. Ustaömer T, Robertson AHF (1999) Geochemical evidence used to test alternative plate tectonic models for pre-Upper Jurassic (Palaeotethyan) units in the Central Pontides, Turkey. Geological Journal 34: 25-53.

5. Eren RHS (1979) Kastamonu-Taşköprü bölgesi metamorfiklerinin jeolojik ve petrografik etüdü. İstanbul Technical University, PhD Thesis.

6. Erol K (2007) Taşköprü-Boyabat Arasında Elekdağ Metaofiyoliti'nin Petrolojik Özellikleri. Hacettepe University, PhD Thesis.

7. Yılmaz Y, Tüysüz O (1988) Kargı masifi ve dolaylarında Mesozoyik tektonik birliklerinin düzenlenmeleri sorununa bir yaklaşım. Bulletin of Petroleum Geologists of Turkey 1: 73-86.

8. Guilbert JM, Park CF (1986) The geology of ore deposits. New York, WH Freeman, 985.

9. Hannington MD, Thompson G, Rona PA, Scott SD (1988) Gold and native copper in supergene sulphides from the Mid-Atlantic Ridge. Nature 333: 64-66.

10. Hannington MD (1993) The formation of atacamite during weathering of sulfides on the modern seafloor. The Canadian Mineralogist 31: 945-956. 
11. Herzig PM, Hannington MD, Scott SD, Maliotis G, Rona PA, et al. (1991) Gold-rich sea-floor gossans in the Troodos ophiolite and on the Mid-Atlantic Ridge. Economic Geology 86: 1747-1755.

12. Scott KM, Ashley PM, Lawie DC (2001) The geochemistry, mineralogy and maturity of gossans derived from volcanogenic $\mathrm{Zn}-\mathrm{Pb}-\mathrm{Cu}$ deposits of the eastern Lachlan Fold Belt, NSW, Australia. Journal of Geochemical Exploration 72 : 169-191.

13. Boyle DR (1996) Supergene base metals and precious metals. In: Eckstrand OR, Sinclair WD, Thorpe RI, Geology of Canadian mineral deposit types. Geologic Survey of Canada, Geology of Canada no. 8, Geological Society of America, Decade of North American Geology, 92-108.
14. Boyle DR (2003) Preglacial weathering of massive sulfide deposits in the Bathurst mining camp-Economic geology, geochemistry, and exploration applications. In: Goodfellow WD, McCutcheon SR, Peter JM, Massive sulfide deposits of the Bathurst mining camp, New Brunswick, and northern Maine. Economic Geology Monograph 11, 689-721.

15. Nieto JM, Capitán A, Sáez R, Almodóvar GR (2003) Beudantite: $A$ natural sink for $\mathrm{As}$ and $\mathrm{Pb}$ in sulphide oxidation processes. Applied Earth Science 112: 293-296.

16. Özdemir A, Şahinoğlu A (2018) Comparison of Iberian Pyrite Belt (IBP) and Central Pontides: Preliminary geological, tectonic and mining geology findings. Journal of Applied Geology and Geophysics 6: 75-95. 